\title{
Standards of care for hypoparathyroidism in adults: a Canadian and International Consensus
}

\author{
Aliya A Khan ${ }^{1}$, Christian A Koch², Stan Van Uum ${ }^{3}$, Jean Patrice Baillargeon ${ }^{4}$, Jens Bollerslev ${ }^{5}$, \\ Maria Luisa Brandi ${ }^{6}$, Claudio Marcocci ${ }^{7}$, Lars Rejnmark ${ }^{8}$, Rene Rizzoli ${ }^{9}$, M Zakarea Shrayyef ${ }^{10}$, Rajesh Thakker ${ }^{11}$, \\ Bulent 0 Yildiz $^{12}$ and Bart Clarke ${ }^{13}$
}

${ }^{1}$ McMaster University, Hamilton, Ontario, Canada, ${ }^{2}$ Technische Universitat Dresden, Dresden, Germany, ${ }^{3}$ Western University, London, Ontario, Canada, ${ }^{4}$ Université de Sherbrooke, Sherbrooke, Quebec, Canada, ${ }^{5}$ Oslo University Hospital, Oslo, Norway, ${ }^{6}$ University of Florence, Florence, Italy, ${ }^{7}$ University of Pisa, Pisa, Italy, ${ }^{8}$ Aarhus University, Aarhus C, Denmark, ${ }^{9}$ University Hospital of Geneva, Geneva, Switzerland, ${ }^{10}$ University of Toronto, Toronto, Canada, ${ }^{11}$ University of Oxford, Oxford, UK, ${ }^{12}$ Hacettepe University School of Medicine, Ankara, Turkey, and ${ }^{13}$ Mayo Clinic, Rochester, Minnesota, USA

Correspondence should be addressed to A A Khan Email

aliya@mcmaster.ca

\begin{abstract}
Purpose: To provide practice recommendations for the diagnosis and management of hypoparathyroidism in adults. Methods: Key questions pertaining to the diagnosis and management of hypoparathyroidism were addressed following a literature review. We searched PubMed, MEDLINE, EMBASE and Cochrane databases from January 2000 to March 2018 using keywords 'hypoparathyroidism, diagnosis, treatment, calcium, PTH, calcidiol, calcitriol, hydrochlorothiazide and pregnancy'. Only English language papers involving humans were included. We excluded letters, reviews and editorials. The quality of evidence was evaluated based on the Grading of Recommendations Assessment, Development and Evaluation (GRADE) approach. These standards of care for hypoparathyroidism have been endorsed by the Canadian Society of Endocrinology and Metabolism.

Results: Hypoparathyroidism is a rare disease characterized by hypocalcemia, hyperphosphatemia and a low or inappropriately normal serum parathyroid hormone level (PTH). The majority of cases are post-surgical (75\%) with nonsurgical causes accounting for the remaining $25 \%$ of cases. A careful review is required to determine the etiology of the hypoparathyroidism in individuals with nonsurgical disease. Hypoparathyroidism is associated with significant morbidity and poor quality of life. Treatment requires close monitoring as well as patient education. Conventional therapy with calcium supplements and active vitamin D analogs is effective in improving serum calcium as well as in controlling the symptoms of hypocalcemia. PTH replacement is of value in lowering the doses of calcium and active vitamin $D$ analogs required and may be of value in lowering long-term complications of hypoparathyroidism. This manuscript addresses acute and chronic management of hypoparathyroidism in adults.

Main conclusions: Hypoparathyroidism requires careful evaluation and pharmacologic intervention in order to improve serum calcium and control the symptoms of hypocalcemia. Frequent laboratory monitoring of the biochemical profile and patient education is essential to achieving optimal control of serum calcium.
\end{abstract}

\section{Introduction}

Hypoparathyroidism is an uncommon disorder that is characterized by hypocalcemia and hyperphosphatemia due to low or inappropriately normal serum levels of parathyroid hormone (PTH). The most common cause of hypoparathyroidism is neck surgery, ( $75 \%$ of the cases) during which parathyroid glands are inadvertently injured, https://eje.bioscientifica.com https://doi.org/10.1530/EJE-18-0609 Printed in Great Britain

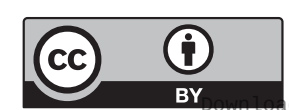

This work is licensed under a Creative Commons Attribution 4.0 International License. 
removed or deprived of their blood supply. The causes of nonsurgical hypoparathyroidism which comprise the remaining $25 \%$ of the cases are listed in Table 1 . PTH resistance syndromes have the same biochemical profile as hypoparathyroidism however PTH levels are elevated.

Conventional therapy of hypoparathyroidism consists of the use of calcium supplements, and active vitamin D. This therapeutic approach addresses the hypocalcemia of hypoparathyroidism, but fails to provide a physiologic replacement for the lack of PTH. Replacement therapy with recombinant human PTH $(\operatorname{rhPTH}(1-84))$ is now approved in the United States and Europe as an adjunctive treatment for adult patients with chronic hypoparathyroidism who cannot be well controlled on conventional therapy management of hypoparathyroidism during pregnancy is challenging with very limited data currently available to guide clinical practice. Canadian Endocrine Update, McMaster University, Western University and the Mayo Clinic formed a working group comprising of parathyroid experts as well as general endocrinologists. Key questions addressing the diagnosis and management of hypoparathyroidism were addressed following an extensive review of the literature. These recommendations reflect current evidence and consensus regarding the appropriate standard of care today. These practice recommendations are to be applied in the context of clinical care with appropriate adjustments for comorbidities, individual preferences as well as other patient factors. They do not preclude clinical judgment and reflect the limited clinical trial evidence available today.

\section{Methodology}

We searched PubMed, MEDLINE, EMBASE and Cochrane databases from January 2000 to March 2018 using keywords 'hypoparathyroidism, diagnosis, treatment, calcium, PTH, calcidiol, calcitriol, hydrochlorothiazide and pregnancy'.

Table 1 Causes of nonsurgical hypoparathyroidism.

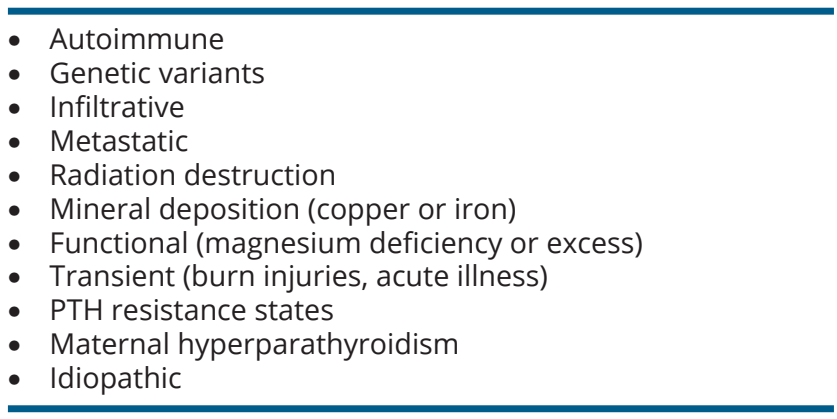

MeSH terms were utilized in various combinations to increase search sensitivity. The search strategy was adapted to PubMed to search for articles published ahead of print (Figure 1). Of the 482 citations, we included only English language papers involving humans. We excluded letters, reviews and editorials. As evidence is limited for certain questions being addressed, we included case reports and case series. Evaluation of the quality of evidence was performed based on the Grading of Recommendations Assessment, Development and Evaluation (GRADE) approach (1) (Table 2). Papers were identified by content experts (A K and B C). Landmark papers published earlier then 2000 were also included if the findings have not been superseded by more recent data. All co-authors contributed to the development of this standards paper. The key questions, results of the literature review and practice recommendations were presented at the Endocrine Society annual meeting in March 2018 in a symposium session entitled '2018 Parathyroid Summit: A Focus on Hypoparathyroidism.' The session included time for attendee feedback, which was incorporated into the current manuscript.

This concise document outlines acceptable care today based on current evidence and consensus. We provide tables and tools to simplify, enhance and standardize treatment.

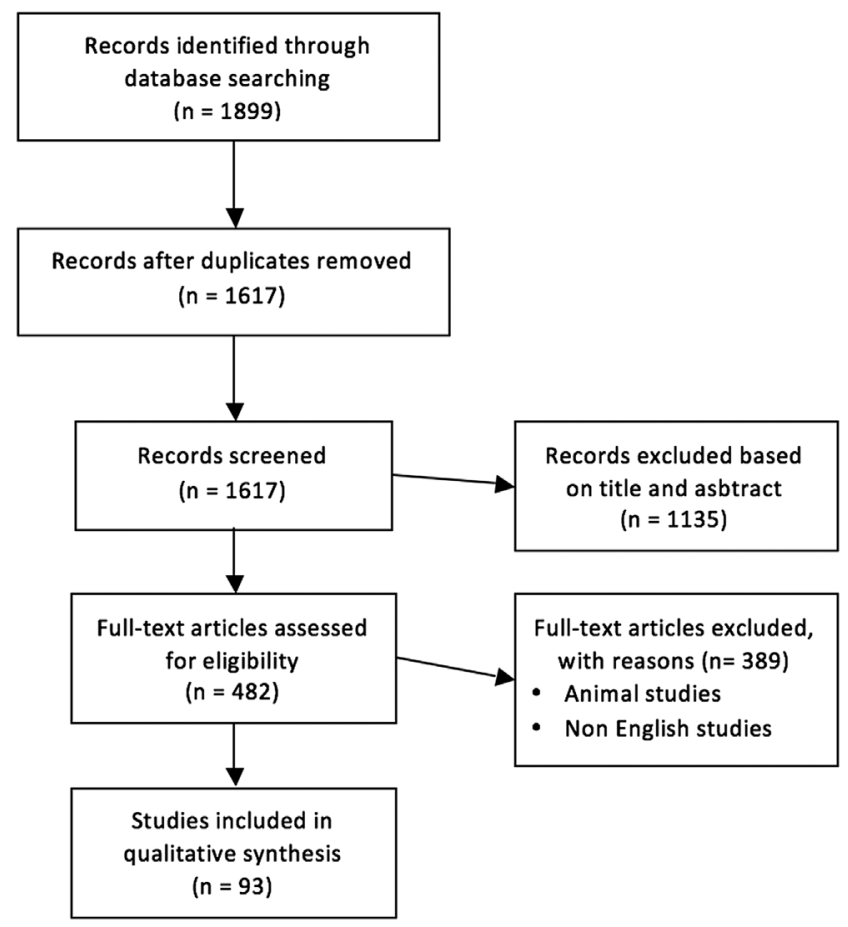

Figure 1

Flow diagram. 
Table 2 Quality assessment criteria (1).

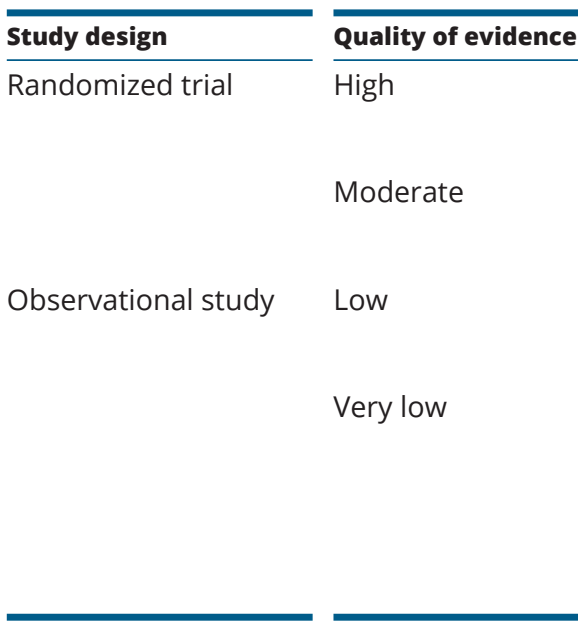

\section{Lower if}

Risk of bias

$(-1)$ Serious

$(-2)$ Very serious

Inconsistency

$(-1)$ Serious

$(-2)$ Very serious

Indirectness

$(-1)$ Serious

$(-2)$ Very serious

Imprecision

$(-1)$ Serious

$(-2)$ Very serious

Publication bias

$(-1)$ Likely

$(-2)$ Very likely

\section{Confirming a diagnosis of hypoparathyroidism and evaluating target organ damage}

(a) How is chronic hypoparathyroidism diagnosed?

In patients with history of thyroid, parathyroid, laryngeal or other neck surgeries, the temporal proximity of the surgical procedure to the development of hypocalcemia, as well as the duration of hypocalcemia, will determine whether this is acute and/or transient hypoparathyroidism (surgery $<6$ months prior) or chronic and permanent hypoparathyroidism (surgery $>6$ months prior) $(2,3,4,5,6,7)$. A low serum albumin-adjusted calcium $<2.0 \mathrm{mmol} / \mathrm{L}$ or $<8 \mathrm{mg} / \mathrm{dL}$ in the presence of a low PTH $<15 \mathrm{pg} / \mathrm{mL}$ is associated with a high risk of permanent hypoparathyroidism and requires appropriate supplementation with calcium and active vitamin D metabolites and follow-up $(8,9)$.

Hypocalcemia for six or more months after surgery, with or without symptoms in the presence of a low or inappropriately normal PTH is diagnostic of permanent surgical hypoparathyroidism. Classic symptoms of hypoparathyroidism principally reflect the effects of hypocalcemia, and may involve neuromuscular, neurologic, behavioral/psychiatric and cardiovascular systems and include numbness and tingling in face, hands or feet, muscle cramping, twitching, depression, irritability, confusion, seizures, bradyarrythmias, wheezing and laryngospasm. Laboratory testing should confirm a low albumin-corrected total serum calcium level or a low ionized calcium levels and low PTH on at least two occasions (emergent care for hypocalcemia should not be delayed and does not require two test results for confirmation of hypocalcemia). If the PTH is

Higher if
Large effect
(+1) Large
(+2) Very large
Dose response
$(+1)$ Evidence of a gradient
All plausible confounding
$(+1)$ Would reduce a demonstrated effect or
$(+1)$ Would suggest a spurious effect when results show no effect

in the normal reference range and is not elevated in the presence of hypocalcemia, this would also be indicative of impaired parathyroid response to the hypocalcemic insult and diagnostic of hypoparathyroidism (3). In nonsurgical patients, obtaining the family history is essential along with assessing other clinical features that are part of complex syndromes in which hypoparathyroidism is a component $(4,5)$. Genetic testing is available to diagnose the molecular basis for the disorder (Table 3).

\section{Nonsurgical causes of hypoparathyroidism}

\section{Autoimmune hypoparathyroidism}

Autoimmune hypoparathyroidism is the most common cause of nonsurgical hypoparathyroidism. It may occur in isolation or as part of the autoimmune polyendocrine syndrome1 (APS1). APS1 is caused by mutations in the autoimmune regulator gene (AIRE), which is expressed in the lymph nodes, thymus, pancreas, adrenal cortex and fetal liver $(10,11)$.

APS1 is associated with circulating autoantibodies and infiltration of the involved organs with lymphocytes resulting in organ failure. APS1 is characterized by three majorclinicalfeatures: chronicmucocutaneouscandidiasis, hypoparathyroidism and adrenal insufficiency. More than $80 \%$ of APS1 patients have hypoparathyroidism, and this may be the only endocrinopathy present $(12,13)$.

Patients may have in addition more than 20 minor clinical features $(3,5)$ (Table 4). The diagnosis of APS1 is probable in the presence of at least one major syndrome and positive antibodies to type 1 interferons, which are present in $>95 \%$ of patients (12). Autoantibodies to 21-hydroxylase correlate with the development of adrenal 
Table 3 Genetic causes of hypoparathyroidism - key clinical findings and lab tests.

\begin{tabular}{l} 
Disorder \\
\hline Autosomal dominant \\
hypoparathyroidism \\
(ADH) type 1 and 2 \\
ADH type 1 with Bartter's \\
syndrome type 5 \\
Isolated \\
hypoparathyroidism \\
Autosomal recessive \\
Autosomal dominant \\
X-linked recessive \\
Hypoparathyroidism of \\
autoimmune etiology \\
Autoimmune mediated \\
Autoimmune \\
polyendocrine syndrome \\
type 1 (APS1) \\
Isolated
\end{tabular}

Isolated

Hypoparathyroidism, deafness, renal anomalies (HDR) syndrome

DiGeorge syndrome
Clinical or laboratory features prompting consideration of specific genetic or other types of testing

Typically asymptomatic or mild hypocalcemia with or without hypercalciuria (ADH types 1 and 2)

Hypocalcemia, hypomagnesemia, hypokalemia, alkalosis, hypercalciuria, and salt and water depletion may be seen depending on the severity

Presentation dominated by biochemical and clinical features of hypoparathyroidism

Other autoimmune diseases and features such as mucocutaneous candidiasis, adrenal insufficiency and hypogonadism May show only hypoparathyroidism

Sensorineural deafness, renal anatomic abnormalities and renal dysfunction, autosomal dominant inheritance

Cardiac defects (present in $\sim 80 \%$ including ventriculoseptal defect, tetralogy of Fallot, interrupted aortic arch, truncus arteriosus), immunodeficiency (recurrent infections, thymic hypoplasia or aplasia, T cell lymphopenia), hypoparathyroidism, pharyngeal and laryngeal abnormalities, cleft palate, behavioral and psychiatric problems, ophthalmic anomalies, hearing loss

Kenny-Caffey syndrome

Type 1 or Sanjad-Sakati syndrome (autosomal recessive)

Type 2 (autosomal dominant)
Short stature, growth retardation, small hands and feet, cortical thickening and medullary stenosis of the long bones, delayed fontanelle closure, abnormal eyes, dysmorphic facies, hypoparathyroidism

Gracile bone dysplasia, short stature with cortical thickening and medullary stenosis of tubular bones, delayed closure of anterior fontanelle, eye abnormalities, and hypoparathyroidism

\begin{tabular}{l}
\hline Molecular defect \\
\hline Gain of function \\
mutation in CASR \\
(type 1) or G alpha \\
11 (type 2) \\
CASR
\end{tabular}

Genetic and other testing to establish diagnosis

CASR or GNA11 sequencing

CASR sequencing

PTH, GCM2, sequencing depending on presentation

PTH or GCM2

PTH or GCM2

sOX3 locus (in males)

Usually due to homozygous mutations in AIRE

AIRE mutations or of unknown etiology

GATA3

AIRE sequencing

Presence of 21-hydroxylase antibodies supports diagnosis of autoimmune adrenal insufficiency

Testing for other hormonal insufficiency states (e.g., adrenal and gonadal insufficiency)

AIRE sequencing

GATA3 sequencing, hearing testing, renal imaging

Variety of defects and deletions and microdeletions in chromosome 22q11.2

TBCE

Fluorescence in situ hybridization (FISH) is the traditional test most commonly done

Two other diagnostic approaches are used with greater frequency than FISH including PCR-based multiplex ligation-dependent probe amplification and SNP) array. In some case, TBX sequencing is done

TBCE sequencing

FAM111A

FAM111A sequencing 
Table 3 Continued.

\begin{tabular}{|c|c|c|c|}
\hline Disorder & $\begin{array}{l}\text { Clinical or laboratory features prompting } \\
\text { consideration of specific genetic or other } \\
\text { types of testing }\end{array}$ & Molecular defect & $\begin{array}{l}\text { Genetic and other testing to } \\
\text { establish diagnosis }\end{array}$ \\
\hline $\begin{array}{l}\text { Hypoparathyroidism } \\
\text { associated with } \\
\text { mitochondrial disorders }\end{array}$ & & $\begin{array}{l}\text { Mutations in the } \\
\text { mitochondrial } \\
\text { genome }\end{array}$ & Mitochondrial DNA sequencing \\
\hline Kearns Sayre syndrome & $\begin{array}{l}\text { Ophthalmoplegia, retinal pigmentary and } \\
\text { cardiac conduction abnormalities, } \\
\text { proximal and bulbar weakness, possibly } \\
\text { ataxia }\end{array}$ & $\begin{array}{l}\text { mtDNA large-scale } \\
\text { deletion }\end{array}$ & $\begin{array}{l}\text { Specialized clinical assessments } \\
\text { depending on the } \\
\text { manifestations (cardiac, } \\
\text { ophthalmologic, neurologic, } \\
\text { endocrinologic and others) }\end{array}$ \\
\hline MELAS & $\begin{array}{l}\text { Encephalomyopathy, lactic acidosis, and } \\
\text { stroke-like episodes along with external } \\
\text { ophthalmoplegia, diabetes, hearing loss, } \\
\text { early-onset stroke symptoms, migraine, } \\
\text { and cognitive dysfunction }\end{array}$ & $\begin{array}{l}\text { Mutations in the } \\
\text { mitochondrial } \\
\text { tRNA Leu gene }\end{array}$ & \\
\hline MTPDS & $\begin{array}{l}\text { Disordered fatty acid oxidation associated } \\
\text { with neuropathy, retinopathy and fatty } \\
\text { liver }\end{array}$ & $\begin{array}{l}\text { Mutations in } \\
\text { mitochondrial } \\
\text { genome }\end{array}$ & \\
\hline
\end{tabular}

AIRE, autoimmune regulator of endocrine function; CASR, calcium-sensing receptor; GNA11; G protein alpha subunit 11; MELAS, mitochondrial encephalomyopathy, lactic acidosis, and stroke-like syndrome; MTPDS, mitochondrial trifunctional protein deficiency.

insufficiency and antibodies to NALP5 correlate with the development of hypoparathyroidism and measuring these antibodies can be of value in predicting the development of adrenal insufficiency and hypoparathyroidism respectively A molecular diagnosis can be confirmed with DNA studies of the AIRE gene (14).

Activating antibodies to the calcium-sensing receptor can suppress PTH secretion leading to hypoparathyroidism (15). Antibodies against the extracellular domain of the CASR have been identified in individuals with autoimmune hypoparathyroidism (16).

\section{Genetic variants}

Genetic causes of hypoparathyroidism is presented in Table 3.

\section{A. Isolated hypoparathyroidism}

a. Glial cells missing (GCM2) gene mutation results in isolated hypoparathyroidism with early onset of hypoparathyroidism due to parathyroid gland agenesis (17). b. Autosomal dominant hypocalcemia (ADH).

Type 1 is caused by an activating mutation in the calcium-sensing receptor (CASR) gene which increases the sensitivity of the CASR to extracellular ionized calcium. The mutated receptor is expressed in the parathyroid glands causing suppression of PTH synthesis and secretion at normal ionized calcium levels leading to hypoparathyroidism (17). In the kidney, the mutated receptor results in enhanced urine calcium losses with relative hypercalciuria and an increased risk of nephrocalcinosis and nephrolithiasis.

Type 2 is caused by an activating mutation in the guanine nucleotide-binding protein alpha 11 (GNA11) gene encoding the alpha subunit of the G protein G11 - a key mediator of CASR signaling resulting in suppresion of PTH even at low serum calcium levels $(18,19)$. Urine calcium excretion is not affected in type $2 \mathrm{ADH}(20)$.

c. PTH gene mutations:

Rare mutations in the PTH gene located on locus 11 p15 have been associated with defective synthesis and secretion of PTH (21).

Table 4 Features of APS1.

\section{Major features}

- Mucocutaneous candidiasis

- Hypoparathyroidism

- Adrenal insufficiency

Minor features

- Keratitis

- Autoimmune hepatitis

- Primary ovarian failure

- Enamel hypoplasia

- Enteropathy with chronic diarrhea or constipation

- Photophobia

- Periodic fever with rash

- Pneumonitis

- Nephritis

- Pancreatitis

- T1DM

- Functional asplenia

- Celiac disease

- Thyroiditis

- Retinitis

- Pure red-cell aplasia

- Polyarthritis 


\section{B. Hypoparathyroidism with additional features (Table 3)}

a. DiGeorge syndrome is a rare condition affecting $1 / 4000-$ 5000 live births, 70-80\% carry a microdeletion within 22q.21-q11.23 chromosome. The clinical features include developmental delay, palatal anomalies, parathyroid aplasia or hypoplasia causing neonatal hypocalcemia, aplastic or hyoplastic thymus with immune deficits, congenital heart defects, facial anomalies, speech and learning disabilities $(22,23,24)$.

b. Hypoparathyroidism, sensorineural deafness and renal dysplasia syndrome (HDR syndrome).

This is a rare autosomal dominant disorder associated with mutations or deletions in the GATA-binding protein 3 gene localized to chromosomal region 10p14-15 resulting in haploinsufficiency of the transcription factor GATA 3, a protein critical for normal parathyroid, kidney and otic vesicle development. The presentation includes the presence of hypocalcemia, hearing loss and renal disease $(25,26)$.

c. Hypoparathyroidism-retardation-dysmorphism (HRD) syndrome. HRD syndrome is a rare form of autosomal recessive hypoparathyroidism which encompasses the two syndromes namely the Sanjad-Sakati and the Kenney Caffey syndromes type 1 and type 2 . The clinical features include congenital hypoparathyroidism, severe growth impairment, mental retardation and facial dimorphism $(27,28,29)$.

\section{Infiltrative causes}

Destruction of the parathyroid glands secondary to granulomatous infiltration (e.g. sarcoidosis, amyloidosis, Riedel's thyroiditis) has been reported $(30,31,32,33,34)$.

\section{Metastatic cancer}

Infiltrating secondary tumors very rarely cause hypoparathyroidism. The most common tumors are breast, leukemia, skin, lung, sarcomas and lymphomas (35).

\section{Radiation destruction}

Rarely high doses of ionizing radiation exposure have been associated with hypoparathyroidism $(36,37,38)$.

\section{Mineral deposition}

Wilson's disease with copper deposition in the parathyroid glands has been reported to be a cause of hypoparathyroidism (39, 40, 41). Hemochromatosis is caused by iron overload and can cause hypoparathyroidism. Iron overload can also occur with repeated transfusions and can develop in individuals with thalassemia $(42,43,44)$.

\section{Transient hypoparathyroidism}

Severe burn injuries and acute illness can be associated with transient hypoparathyroidism $(45,46)$.

\section{Functional hypoparathyroidism (magnesium deficiency or excess)}

Both hypomagnesemia and hypermagnesemia can impair parathyroid function. Abnormalities in serum magnesium require further evaluation and correction (Tables 5 and 6). Magnesium is reabsorbed in the kidney and absorbed in the bowel in a passive paracellular manner $(47,48)$. Transcellular absorption of $\mathrm{Mg}^{+2}$ occurs via the transient receptor potential melastatin subtype 6 (TRPM6) channels in the bowel and kidney (48). $\mathrm{Mg}^{+2}$ can activate the CASR and lower PTH synthesis and secretion $(49,50)$. Activation of the CASR by $\mathrm{Mg}^{+2}$ stimulates phospholipase $\mathrm{C}$ and $\mathrm{A} 2$ and inhibits cellular cAMP with inhibition of PTH release (51). Thus, high serum magnesium levels can decrease PTH and contribute to hypocalcemia. Activation of the CASR in the kidneys results in decreased paracellular transport of both calcium and magnesium in the kidneys.

Table 5 Causes of low magnesium.

Causes of low magnesium

- Decreased intake

- Decreased intestinal absorption (malabsorption, short bowel syndrome, severe vomitting, diarrhea, steatorrhea)

- Familial hypomagnesemia with secondary hypocalcemia (TRPM6 mutation)

- Autosomal dominant hypocalcemia (activating mutation in CASR gene)

- Familial hypomagnesemia with hypercalciuria and nephrocalcinosis (FHHNC)

Drugs

- Thiazides, furosemide

- Proton pump inhibitor

- Antibiotics

- Antimycotics (foscarnet, amphotericin B, aminoglycosides, pentamidine, rapamycin)

- Anticancer drugs (cisplatin, carboplatin)

- Immunosuppressants (calcineurin inhibitors-tacrolimus, cyclosporine A)

- EGF-receptor inhibitors (cetuximab) 
Table 6 Causes of high serum magnesium.

- Chronic kidney disease

- Familial hypocalciuric hypercalcemia

- Excess intake (cathartics, laxatives, parenteral $\mathrm{Mg}^{+2}$ )

- Tocolytic therapy for eclampsia

Activating mutations of the CASR result in $\mathrm{ADH}$ with hypocalcemia as well as hypomagnesemia in a significant number of patients (52).

Mutations in the claudin proteins (claudin 16 and 19) impair paracellular renal reabsorption of both calcium and magnesium causing familial hypomagnesemia with hypercalciuria and nephrocalcinosis (FHHNC) $(52,53,54)$.

Loss-of-function mutations in TRPM6 channels affect active transcellular $\mathrm{Mg}^{+2}$ transportation in both the kidney and the bowel and result in hypomagnesemia with secondary hypocalcemia (HSH) $(55,56)$. Severe hypomagnesemia blocks PTH synthesis and secretion by increasing inhibitory $\mathrm{G}$ alpha subunit activity (57).

A resistance to PTH at the skeletal level is also seen in hypomagnesemia as intracellular $\mathrm{Mg}^{+2}$ is a cofactor of adenylate cyclase and decreases in intracellular $\mathrm{Mg}^{+2}$ lead to a resistance to PTH (57). Magnesium plays a key role in calcium homeostasis and should be evaluated and normalized. A more accurate assessment of magnesium stores can be obtained by measuring the red blood cell magnesium (47). In the presence of hypomagnesemia assessing urinary magnesium can be helpful. Measuring the fractional excretion of magnesium enables differentiation of renal magnesium losses from intestinal losses (FEMg=urine $\mathrm{Mg} \times$ plasma $\mathrm{Cr} / 0.7 \times$ plasma $\mathrm{Mg} \times$ urine creatinine $\times 100 \%)$. If $\mathrm{FEMg}$ $>4 \%$ in the presence of hypomagnesemia, this would be consistent with renal magnesium wasting (58). An extra renal cause of magnesium loss is likely to be present if FEMg $<2 \%$ (58).

\section{Mitochondrial disorders associated with hypoparathyroidism}

Kearns-Sayer syndrome is characterized by opthalmoplegia ptosis, retinitis pigmentosa, cardiomyopathy, cardiac conduction blocks as well as ataxia.

Mitochondrial myopathy, encephalopathy, lactic acidosis, stroke-like episodes (MELAS) syndrome presents with muscle weakness and affects the central nervous system $(59,60)$.

\section{Maternal hyperparathyroidism}

Infants exposed in utero to maternal primary hyperparathyroidism may develop suppressed parathyroid function and hypocalcemia $(61,62,63)$.

\section{PTH resistance syndromes}

Pseudohypoparathyroidism (PHP) is characterized by target organ resistance to PTH. The biochemical profile is the same as seen in hypoparathyroidism with low serum calcium and high phosphate; however, PTH levels are elevated. PHP type 1 is associated with maternal loss of function mutations in the GNAS1 gene, which encodes the alpha subunit of the stimulatory G protein (Gsa) coupled to the PTH receptor. These mutations result in the inability of the G protein to activate adenylate cyclase upon binding of PTH to its receptor leading to failure of signal transduction to produce an end-organ response to PTH (64). The manifestations of PHP depend on whether the mutation is maternally or paternally transmitted (65) (Table 3).

\section{PHP type 1a (GNAS1 mutation on maternally inherited allele)}

The clinical features of PHP type 1a include Albright hereditary osteodystrophy (AHO) - which refers to a constellation of developmental and skeletal defects, which include short stature, obesity, dental hypoplasia, mental retardation, frontal bossing, short neck, round face, subcutaneous calcification, shortened fourth and fifth metacarpals and metatarsals (brachydactyly) and developmental delay. Resistance to other G-proteincoupled hormones may be present including gonadotropins, TSH and GHRH $(66,67)$. The biochemical profile demonstrates low calcium, high phosphate and high PTH.

\section{PHP $1 b$ (GNAS1 mutation or STX gene mutation)}

This condition is associated with a mutation in the cisacting element of GNAS1 resulting in reduction or complete absence of alpha subunit of stimulatory $G$ protein in the proximal renal tubules. The PTH resistance is confined to the kidney $(68,69)$. There are no clinical features of AHO. The biochemical profile demonstrates PTH resistance with low calcium, high phosphate and high PTH. Usually there is no resistance to other hormones. 


\section{PHP1C (GNAS mutation on maternally inherited allele)}

Clinical features of $\mathrm{AHO}$ are present as well as resistance to PTH and other hormones.

The GNAS1 mutation affects coupling of G proteins to the PTH receptor. Gsa is normal in quantity and activity, ability to stimulate adenylate cyclase is intact (70).

\section{Pseudo-PHP (GNAS mutation on paternally inherited alleles)}

This condition is secondary to paternally transmitted inactivating GNAS1 mutation. AHO is present without the renal tubular resistance to PTH. The paternal allele of GNAS1 is always silenced due to genetic imprinting and if the maternal allele is normal, the biochemical profile is normal (71). Laboratory profile includes normal calcium, phosphate and PTH.

\section{Progressive osseous heteroplasia}

A paternally inherited inactivating mutation in the GNAS1 gene results in progressive osseous heteroplasia (72). The clinical features include extensive ectopic bone formation in the skin, muscles and connective tissues as well as AHO. Laboratory profile includes normal calcium, phosphate and PTH.

\section{Idiopathic}

If the cause of the hypoparathyroidism is not identified following a careful clinical and laboratory evaluation, the condition can be confirmed as idiopathic in etiology.

\section{Key points:}

The diagnosis of hypoparathyroidism is made in the presence of low serum calcium (ionized or adjusted for albumin) and low or inappropriately normal PTH confirmed on two separate occasions. Further evaluation enables identification of the cause of hypoparathyroidism in nonsurgical cases. In young individuals or consanguineous parents a referral to a geneticist is advised for appropriate genetic counseling. DNA studies enable a molecular diagnosis to be made.

\section{Quality of evidence: low.}

(b) How do we evaluate target organ damage in hypoparathyroidism?

Hypercalciuria is commonly seen in chronic hypoparathyroidism on treatment, and may lead to nephrocalcinosis, nephrolithiasis and renal insufficiency.
Renal complications are assessed by regular monitoring of renal function (eGFR and serum creatinine) as well as assessment for hypercalciuria with a 24-h urine calcium and creatinine assessment $(5,73,74,75)$. Renal imaging with ultrasound is recommended with identification of nephrocalcinosis or nephrolithiasis $(76,77)$. If ocular complications (posterior subcapsular cataracts) are suspected, a slit lamp examination is performed (5, $73,74)$. The development of neurocognitive decline, movement disorders or seizures may indicate brain calcification, which are evaluated by brain imaging and an electroencephalogram. In the absence of these symptoms, the role of brain imaging to monitor these complications is unclear.

\section{Key points:}

The risk for and extent of renal complications are assessed by evaluating renal function (eGFR), a 24-h urine for calcium excretion, and a renal ultrasound for the presence of nephrocalcinosis or nephrolithiasis. Brain imaging is advised in the presence of cognitive impairment, movement disorders or seizures. Opthalmoscopic examination enables assessment for the development of cataracts and can be completed in the presence of symptoms or concerns.

\section{Quality of evidence: low.}

(c) How frequently should biochemical and clinical assessment be performed?

Current consensus supports regular monitoring of (a) serum chemistries including calcium corrected for albumin (or ionized calcium), phosphorus, magnesium, urea nitrogen and creatinine every 3-6 months; (b) urinary calcium excretion, creatinine and sodium (either by 24-h urine collection or random urine collection) and 25-hydroxyvitamin D levels (annually); (c) renal calcification by imaging, such as ultrasound, if there is persistent hypercalciuria, a history of renal stones, abnormal urinalysis or a decline in eGFR; (d) signs and symptoms of hypocalcemia and hypercalcemia should be evaluated every 6 months based on the stability of hypoparathyroidism. Asking the patient regarding their overall function is also of value as many symptoms of hypoparathyroidism are nonspecific and include low energy or fatigue or brain fog and may be a marker of poor serum calcium control and (e) basal ganglia calcification can be evaluated with brain CT or susceptibility-weighted MRI (SW-MRI) and the presence of cataracts as part of the routine annual eye examination. The serum calcium and phosphate may require closer monitoring (every 
1-2 weeks) if changes are made in the dose of the calcium or active vitamin $\mathrm{D}$ or if symptoms are present.

\section{Key points:}

Serum and urine biochemistries should be evaluated at least every 6 months for calcium (ionized or albuminadjusted), phosphate, magnesium, 25-hydroxyvitamin $\mathrm{D}$ and annually for 24-h urine calcium and creatinine. Following changes in the dose of calcium or active vitamin $\mathrm{D}$ the lab profile should be repeated in 1-2 weeks.

Quality of evidence: low.

\section{Management of hypoparathyroidism - avoiding complications of treatment}

(a) Are long-term complications a real problem?

Long-term complications include renal impairment, renal stones, nephrocalcinosis as well as cataracts and calcification of the basal ganglia and other regions of the brain (5). Several retrospective studies have shown that long-term complications of hypoparathyroidism are commonly seen. A large cohort study determined the rate of complications in 120 patients with permanent hypoparathyroidism with a mean follow-up of 7.4 years (75). While serum calcium levels were maintained within a calcium range of $7.5-9.5 \mathrm{mg} / \mathrm{dL}(1.9-2.4 \mathrm{mmol} / \mathrm{L})$ for an average of $86 \%$ of the time, the 24 -h urinary calcium analysis in 53 patients showed that $38 \%$ had a least one measurement with hypercalciuria ( $>300 \mathrm{mg} /$ day). Renal imaging in 54 patients showed renal calcification was present in $31 \%$ of the patient population. Compared with age-appropriate historical controls from NHANES, the rates of chronic kidney disease stage 3 or higher were 2- to 17-fold greater in those with hypoparathyroidism. These data have been recently confirmed in another series of 90 patients with chronic post-surgical hypoparathyroidism (6).

In a large case-control study from a national registry in Denmark, the hazard ratio (HR) for developing kidney stones and renal insufficiency in patients with postsurgical hypoparathyroidism was 4.8 and 3.1, respectively (78). In another Danish case-control study, the HR in patients with nonsurgical hypoparathyroidism for developing renal insufficiency was 6.0 (79).

Cataracts have been reported in approximately $50 \%$ of patients with chronic hypoparathyroidism in case series $(80,81)$. In the case-control studies from Denmark, the risk of cataracts was increased in patients with nonsurgical hypoparathyroidism
(HR 4.32) (79), but not in patients with post-surgical hypoparathyroidism (78).

Intracranial calcifications, in particular in the basal ganglia, can develop in patients with hypoparathyroidism $(75,82)$. The exact cause is not known, however, elevated serum phosphate levels or an elevated calcium-phosphate product are thought to be a contributing factor. The clinical significance of basal ganglia calcifications is unclear; symptoms of Parkinsonism and dystonia have also been described in some cases (82).

Serum phosphate and the calcium-phosphate product should be maintained in the normal reference range (i.e. less than $\left.55 \mathrm{mg}^{2} / \mathrm{dL}^{2}\left(4.4 \mathrm{mmol}^{2} \mathrm{~L}^{2}\right)\right)$ as they are thought to contribute to extraskeletal calcifications and other complications when elevated $(73,83,84)$. This does however require further prospective evaluation. If serum phosphate levels are high, calcium supplements can be increased and should be given with meals as they are excellent phosphate binders. The calcium-phosphate product may not correlate with basal ganglia calcification and this requires further prospective evaluation as well as other measures including serum phosphate and the 24-h urine calcium, which may be of value in predicting the presence of extraskeletal calcification (85). The dose of the active vitamin $\mathrm{D}$ can also be reassessed as $1,25(\mathrm{OH}) 2$ increases intestinal calcium absorption as well as phosphorus absorption. Dietary modification with a low phosphate diet (low intake of meat, eggs, cola and dairy) may be implemented as needed on an individual basis. A low-salt diet is also helpful as it lowers renal calcium losses.

\section{Key points:}

In hypoparathyroidism, long-term renal complications and extraskeletal calcification are commonly seen and may be reduced by lowering urine calcium excretion, serum phosphorus and the calcium-phosphate product.

Quality of evidence: very low.

(b) How should acute hypocalcemia be managed?

Depending on the rate of onset, biochemical severity and clinical symptoms, acute hypocalcemia may require management in hospital with intravenous calcium. Calcium gluconate is the preferred salt to be administered intravenously as it is less irritating to the veins than calcium chloride. A bolus of $1-2 \mathrm{~g}$ of $10 \%$ calcium gluconate (corresponding to $90-180 \mathrm{mg}$ of elemental calcium) in $50 \mathrm{~mL}$ of $5 \%$ dextrose may be administered over $20 \mathrm{~min}$ followed by a continuous infusion of intravenous calcium with $1-3 \mathrm{mg} / \mathrm{kg} / \mathrm{h}$ of elemental calcium administered as 
calcium gluconate. During the calcium bolus and infusion continuous cardiac monitoring is advised. Oral calcium supplements and active vitamin D are also initiated (83, 86). Hypomagnesemia should be corrected (83) and vitamin D levels should be normalized $(2,3)$. Low serum magnesium leads to further suppression of PTH synthesis and secretion (87). This paradoxical inhibition of the parathyroid involves intracellular signaling pathways of the CaSR with an increase in the activity of inhibitory $\mathrm{G}$ alpha subunits (57). Hypomagnesemia also results in a resistance to the effects of PTH in the tissues. PTHinduced bone resorption is impaired in hypomagnesemia $(88,89,90)$. Intracellular $\mathrm{Mg}^{2+}$ is a cofactor of adenylate cyclase and decreases in intracellular ionized $\mathrm{Mg}^{2+}$ lead to resistance to PTH $(91,92,93)$. Hypocalcemia combined with magnesium deficiency is resistant to treatment with $\mathrm{Ca}^{2+}$ or vitamin $\mathrm{D}$, but rapidly responds to $\mathrm{Mg}^{2+}$ supplementation.

There are very little data (largely from case reports) regarding the possible use of rhPTH (1-84) in the management of acute hypocalcemia $(94,95$, 96). Hypoparathyroidism is associated with impaired hydroxylation of 25 hydroxyvitamin D in the kidney as PTH stimulates the formation of 1,25 dihydroxyvitamin D (calcitriol) (97). Therefore, individuals with hypoparathyroidism have a deficiency of both PTH as well as calcitriol. Active vitamin D metabolites are necessary to correct the hypocalcemia and enhance the intestinal absorption of both calcium and phosphate. Calcitriol can be initiated with doses of $0.25 \mu \mathrm{g}$ twice daily and gradually titrated upward to a dose of $2.0 \mu \mathrm{g}$ BID if necessary (2). Occasionally higher doses may be necessary. The halflife of calcitriol is $5-8 \mathrm{~h}$ and the dose can be increased in 48-72 h. Alfacalcidiol (1alpha $(\mathrm{OH}) \mathrm{D} 3)$ can also be used in doses of $0.5-4 \mu \mathrm{g}$ once daily; however, it has a longer time to offset of action (5-7 days) and is not as potent as calcitriol $(98,99)$. Close titration is required to avoid hypercalciuria and hypercalcemia which may contribute to the long-term complications of renal and extra skeletal calcification. Parent vitamin D (D2 or ergocalciferol or D3 cholecalciferol) is of value to ensure that the 25hydroxyvitamin D levels are in the normal reference range ( $75 \mathrm{nmol} / \mathrm{L}$ or higher) (100).

\section{Key recommendation:}

Acute severe hypocalcemia is treated with IV calcium boluses followed by a continuous calcium infusion as well as oral calcium supplements and active vitamin D. Hypomagnesemia must be corrected.

Quality of evidence: low (standard practice). (c) What are practical strategies to lower urinary calcium?

Reducing the filtered renal load of calcium by decreasing serum calcium is the most effective method to lower urinary calcium in chronic hypoparathyroidism. Thiazide diuretics may also be effective in lowering urinary calcium losses especially when combined with a low-salt diet (101). For individuals with ADH type 1 (ADH 1) and ADH 2, thiazide diuretics may further exacerbate the hypokalemia; therefore, extreme caution must be exercised. Distributing calcium supplements evenly throughout the day can avoid peaks of serum calcium, which may contribute to hypercalciuria. Finally, rhPTH(1-84) replacement therapy may also be considered as discussed below (74).

\section{Key recommendation:}

Reduce urinary calcium losses with a low-salt diet and consider hydrocholorothiazide, chlorthalidone or indapamide as tolerated. In the presence of renal complications rhPTH(1-84) may also be considered.

Quality of evidence: low.

\section{Management of hypoparathyroidism in pregnancy and lactation}

(a) What are the physiologic changes in serum calcium and the calcium-regulating hormones during pregnancy?

During pregnancy, calcium requirements increase in order to meet the growing needs of the developing fetal skeleton $(102,103)$. Approximately $80 \%$ of the calcium, phosphorus and magnesium present in the full-term fetal skeleton is accreted during the 3rd trimester (102).

In pregnancy, the intravascular volume expands and with hemodilution, the serum albumin decreases resulting in a low total serum calcium $(104,105)$. The ionized calcium, as well as the albumin-corrected total calcium level remains unchanged in normoparathyroid mothers. PTH-related protein (PTHrP) begins to rise in the 3rd to the 13th week of gestation reaching a three-fold increase in PTHrP levels by term $(106,107,108,109)$. The source of the PTHrP is the placenta and breasts, as well as the uterus $(110,111,112)$.

The lactating breast produces significant levels of PTHrP, which is released into the maternal circulation and enhances renal calcium reabsorption and phosphate excretion as well as bone resorption. PTHrP stimulates Cyp27b1 with increased production of calcitriol, which in turn enhances intestinal calcium and phosphate absorption (113, 114, 115). 
Calcitriol rises in the first trimester and increases two- to three-fold by term as observed in longitudinal studies (106, 116, 117, 118, 119, 120). Longitudinal studies have confirmed a rise in both free and bound calcitriol $(106,116,118)$. Vitamin D-binding proteins rise by approximately $20-40 \%$ during pregnancy and the free and bound calcitriol rises by two- to three-fold resulting in enhanced intestinal calcium and phosphate and enable the mother to achieve a positive calcium balance in the first trimester (102). The rise in calcitriol increases intestinal calcium absorption and suppresses PTH. The kidneys are the main source of the calcitriol with possibly some contribution from other tissues including the placenta and the fetus. Renal expression of Cyp27b1 is 35 -fold higher in maternal kidneys than in the placenta (121). Anephric women on dialysis have low calcitriol levels during pregnancy (122). However, the factors that stimulate renal Cyp27b1 are still not clear. PTHrP, estradiol and prolactin may stimulate renal Cyp27b1 during pregnancy. PTHrP is a weak stimulator of Cyp27b1 in comparison to PTH (123). The 25(OH) D levels are stable during pregnancy despite increased conversion to calcitriol and transfer to the fetus (102, 124). Calcitriol levels fall into the pre-pregnant range during lactation and intestinal calcium absorption normalizes (120, 125, $126,127,128,129)$. Further prospective evaluation of parent and active vitamin $\mathrm{D}$ supplementation is required in hypoparathyroid pregnant women (130).

PTH is suppressed to low normal or below normal levels in the first trimester and reaches mid normal levels by term $(106,108,117,125,126,131,132)$. The PTH levels are impacted by changes in dietary calcium and vitamin D $(102,133)$. During lactation, PTH levels are suppressed or undetectable as noted with the intact PTH assays (102, $125,133,134,135,136)$.

Calcitonin increases during pregnancy and may protect the maternal skeleton from demineralization (102). The source of calcitonin includes the thyroid C-cells as well as the breast and placenta $(137,138)$. Higher levels of estradiol, estrone and estriol may result in increases in serum calcitonin (102). During lactation, calcitonin levels may be normal or increased $(105,118,126,139)$.

In pregnancy, the hypoparathyroid mother requires careful monitoring of serum calcium, phosphate and urinary calcium excretion as the physiologic rises in calcitriol and PTHrP may lower the requirements for calcium and calcitriol during pregnancy. However, case reports of hypoparathyroid women requiring higher doses of calcium and calcitriol during pregnancy have also been published $(140,141,142,143)$. Close monitoring is required during pregnancy to ensure that serum calcium is maintained in the normal reference range.

\section{Key finding:}

Calcium requirements increase during pregnancy due to fetal demands; however, due to rises in PTHrP and calcitriol, the dose requirements for calcium and active vitamin $\mathrm{D}$ in hypoparathyroid mothers may decrease. However, in some patients, dose requirements may increase.

During lactation calcitriol levels normalize. PTHrP levels are high and increase bone resorption and enhance renal calcium reabsorption. These effects may lower the dose requirements for calcitriol and calcium supplementation during lactation in hypoparathyroid patients.

\section{Quality of evidence: low.}

(b) What are the treatment targets for serum calcium during pregnancy?

As calcium requirements increase during pregnancy it is important to ensure that the hypoparathyroid mother is receiving adequate calcium and calcitriol supplementation and is not hypocalcemic as this can result in the development of secondary hyperparathyroidism in the fetus with fetal skeletal demineralization. In contrast, if the mother is hypercalcemic the fetal parathyroid tissue may become suppressed and the neonate may develop hypocalcemia. It is important to closely monitor patients in order to avoid hypocalcemia and hypercalcemia. Uterine irritability increases with hypocalcemia, and this may increase the risk of preterm labor (144).

It is recommended that the total calcium corrected for albumin be maintained in the low to mid normal reference range and this should be evaluated every 3 weeks during pregnancy or more frequently if changes in the calcium supplements or calcitriol dose are being made.

\section{Key recommendation:}

Serum calcium (corrected or ionized) should be maintained in mid-to-low normal reference range. Serum calcium, phosphorus, eGFR and magnesium should be monitored during pregnancy every 3 weeks. If changes in the dose of calcium or calcitriol are recommended, repeat the serum calcium in 1-2 weeks. Maintain the 25-hydroxyvitamin $\mathrm{D}$ and 24-h urine calcium in the normal reference range.

Quality of evidence: very low.

(c) How should management be modified to reduce the risk of maternal and fetal complications? 
Close monitoring of circulating levels of calcium corrected for albumin, phosphate and magnesium is necessary to avoid complications of hypoparathyroidism in pregnancy. Uterine irritability increases with hypocalcemia and may increase risk of preterm labor or miscarriage (144). Ensure that the mother is receiving adequate calcium and calcitriol supplementation to maintain the serum calcium in the normal reference range. Neonatal complications include small for gestational age and respiratory distress syndrome $(140,145,146,147,148)$.

A recent retrospective audit of an Australian database of ten pregnancies with hypoparathyroidism demonstrated that the requirements for calcitriol vary during the second half of pregnancy and decrease substantially during lactation $(148,149)$.

Hydrochlorothiazide should be avoided during pregnancy as it is classified as an FDA pregnancy risk category B drug (150). PTH has not been adequately evaluated in pregnancy. It is classified as an FDA pregnancy risk category $\mathrm{C}$ drug. A case of one patient treated with PTH(1-34) has been reported and the neonate was normal at birth with normal serum calcium (151). The dose of the calcitriol can be adjusted based on the serum ionized or albumin-adjusted calcium with close monitoring during pregnancy every 2-3 weeks for serum calcium (albuminadjusted or ionized) phosphorus and magnesium. The 25-hydroxyvitamin D level should be normalized (75$125 \mathrm{nmol} / \mathrm{L}$ (30-50 ng/mL) (152).

During lactation, monitoring can continue every 4 weeks. Both pregnant and lactating women should be informed of the symptoms of hypo- and hypercalcemia (Table 7) and advised to immediately check their serum calcium if they are not well and seek urgent medical assistance as needed. Care must be co-ordinated between the treating endocrinologist as well as the obstetrician and the pediatrician to ensure optimal maternal and fetal outcomes.

\section{Key recommendation:}

Discontinue thiazide diuretics during pregnancy, adjust the dose of calcium and active vitamin D targeting lowto-mid normal albumin-corrected calcium. Advise the pediatrician to assess the neonate immediately following birth and monitor serum calcium. During lactation continue to monitor serum calcium every 4 weeks and adjust the dose of the calcium and calcitriol supplements targeting mid-to-low normal serum calcium.

Quality of evidence: very low.

\section{4. rhPTH(1-84) replacement therapy in hypoparathyroidism - when and how to proceed?}

A number of key questions arise when considering which patients with chronic hypoparathyroidism should be treated with $\operatorname{rhPTH}(1-84)$ replacement therapy. Replacement therapy with $\operatorname{rhPTH}(1-84)$ has been approved as an adjunct to conventional therapy by regulatory agencies.

(a) Which criteria confirm that conventional therapy for chronic hypoparathyroidism has failed?

Limitations of conventional therapy with calcium, active vitamin $\mathrm{D}$ metabolites and vitamin $\mathrm{D}$ include an inability to alleviate the symptoms of hypocalcemia and to improve quality of life. In the absence of PTH, urinary calcium excretion is elevated and contributes to the long-term complications of hypoparathyroidism which include renal insufficiency, nephrocalcinosis as well as nephrolithiasis (153). Guidelines define failure of conventional treatment of chronic hypoparathyroidism as meeting certain criteria $(73,74)$ : (1) inability to keep serum calcium in the lower half of reference range without symptoms of hypocalcemia, (2) failure to keep serum phosphate within the reference range, (3) inability to keep the calcium-phosphorus product below $55 \mathrm{mg}^{2} /$ $\mathrm{dL}^{2}\left(4.4 \mathrm{mmol}^{2} \mathrm{~L}^{2}\right)$, (4) failure to keep serum magnesium within the reference range, (5) inability to keep urinary calcium within the reference range for weight and gender and 6) failure to maintain long-term well-being and QOL.

In addition, compliance with conventional therapy is often poor and is contributed to by the large number of pills required daily as well as gastrointestinal side effects of supplemental calcium.

\section{Key recommendation:}

Failure of conventional therapy is confirmed in the presence of poor control of serum calcium, the presence of complications of hypoparathyroidism or the presence of a poor quality of life.

Table 7 Symptoms of hypocalcemia and hypercalcemia.

\begin{tabular}{|c|c|}
\hline Hypocalc & $\begin{array}{l}\text { Numbness, tingling in face, hands and feet, muscle spasm, cramps, depression, confusion, seizures, } \\
\text { bradyarrhythmia, wheezing, laryngospasm, congestive heart failure }\end{array}$ \\
\hline Hyp & , polyuria, nausea, anorexia, vomiting, constipation, weakness, headaches, confusion \\
\hline
\end{tabular}

https://eje.bioscientifica.com 
Quality of evidence: low-moderate.

(b) When should rhPTH(1-84) replacement therapy be considered in patients with chronic hypoparathyroidism?

PTH replacement therapy was initially evaluated in hypoparathyroidism with the PTH(1-34) molecule. Subcutaneous twice daily injections of PTH(1-34) maintained mean urine calcium in the normal range, with no difference compared to calcitriol $(154,155)$, whereas intravenous administration using a pump resulted in a marked decline in mean urine calcium well within the normal range, with a significant difference in comparison to calcitriol (156). More recently, PTH(1-34) in doses of $20 \mu \mathrm{g}$ BID led to reductions in the dose of calcium and calcitriol required daily and increased serum calcium while lowering serum phosphate $(157,158)$ (Table 8$)$.

Replacement therapy with $\mathrm{PTH}(1-84)$ maintains serum calcium and phosphate levels in the appropriate range, while reducing the daily doses of calcium and active vitamin D metabolites $(159,160)$. In some patients PTH replacement therapy enables withdrawal of calcium and active vitamin D analogs. The effects on urinary calcium excretion are modest; however, a long-term open-label study suggests a progressive decrease in urinary calcium excretion (161) (Table 8). Skeletal abnormalities (low turnover status, increased bone mineral density (BMD)) are improved. Bone turnover markers increase within 1 year and subsequently decline to levels that are higher than pretreatment values. BMD increases at the lumbar spine and to a lesser extent at the hip, while there is a progressive decline at the distal $1 / 3$ radius (161). Bone histomorphometry studies have shown reductions in trabecular width and an increase in trabecular number. Intratrabecular tunneling has been demonstrated in about half of the biopsy specimens (161). Cancellous bone matrix mineralization is markedly increased in hypoparathyroid bone compared to normal. $\operatorname{rhPTH}(1-84)$ treatment after 1 year is associated with a decrease in the degree of mineralization which returns to the baseline value at year 2 (162). Conversely, the greater heterogeneity detected at 1 year persists (162).

Recently, an increased rate of vertebral fractures has been reported in patients with idiopathic hypoparathyroidism treated with conventional therapy (81). Replacement therapy with $\operatorname{rhPTH}(1-84)$ may have positive skeletal effects on bone strength and fracture risk; however, this requires further evaluation (Table 9).

Several studies have shown that quality of life is reduced in patients with hypoparathyroidism (163, 164, 165 , 166). Short-term placebo-controlled studies have shown either no effect or modest improvement, whereas a long-term open-label study has shown a benefit in all parameters of the SF-36 scale (163).

PTH replacement therapy is well tolerated and adverse events are mild and transient.

No data are currently available on the potential long-term benefits of $\operatorname{rhPTH}(1-84)$ replacement therapy. The FDA has approved $\operatorname{rhPTH}(1-84)$ with a 'black box' warning because of an increased risk of osteosarcoma in rats treated with high doses of $\mathrm{PTH}(1-34)$; however, an increased rate of osteosarcoma has not been observed in humans despite use in more than a million people (167).

As PTH therapy in hypoparathyroidism has been demonstrated to lower the requirements for calcium and active vitamin D analogs and also lower serum phosphate as well in some studies demonstrated reductions urinary calcium excretion, it has been proposed that PTH replacement be considered in the following circumstances;

1. inadequate control of serum calcium,

2. oral calcium or vitamin $\mathrm{D}$ medications required to control serum calcium or symptoms that exceed $2.5 \mathrm{~g}$ calcium or $>1.5 \mu \mathrm{g}$ calcitriol per day,

3. hypercalciuria, renal stones, nephrocalcinosis, stone risk or reduced creatinine clearance or eGFR $(<60 \mathrm{~mL} /$ $\min )$,

4. hyperphosphatemia and/or calcium-phosphate product that exceeds $55 \mathrm{mg}^{2} \mathrm{dL}^{2}\left(4.4 \mathrm{mmol}^{2} \mathrm{~L}^{2}\right)$ (74).

There are many factors contributing to urine calcium including the filtered calcium load as well as the dose of PTH and frequency of administration of this molecule. Further prospective data will enable refinement of administration with a goal to consistently reduce urine calcium excretion.

PTH replacement may also be of value in individuals who have malabsorption or are intolerant of large doses of oral calcium supplements as well as those who are noncompliant with taking several pills each day. PTH replacement therapy may improve quality of life; however, effects of PTH replacement on quality of life require further study as currently controlled studies have not demonstrated reversal of muscle weakness and fatigue with therapy. Wide fluctuations in serum calcium may occur in certain individuals with hypoparathyroidism particularly following exercise or with intercurrent illness and may result in hospitalization. Overcorrection of hypocalcemia may lead to hypercalcemia and individuals with wide fluctuations in serum calcium require close monitoring ideally with a calcimeter which can provide immediate measures of serum calcium in real time. 


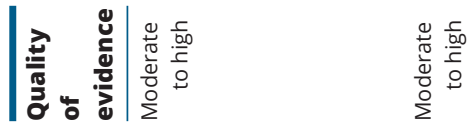
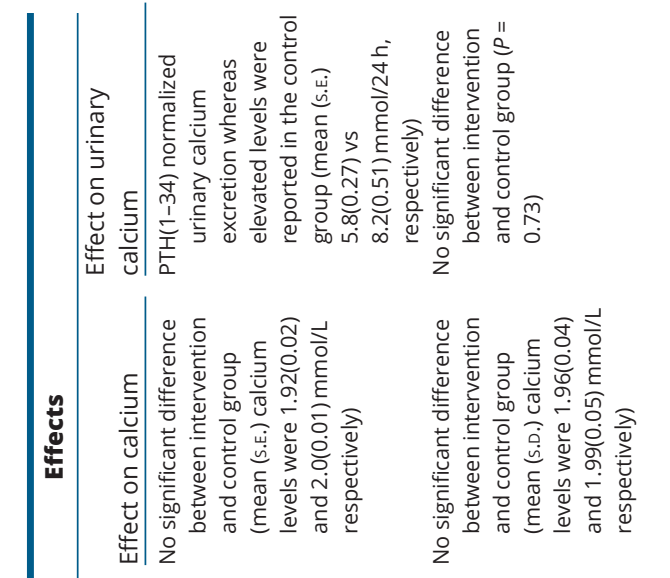

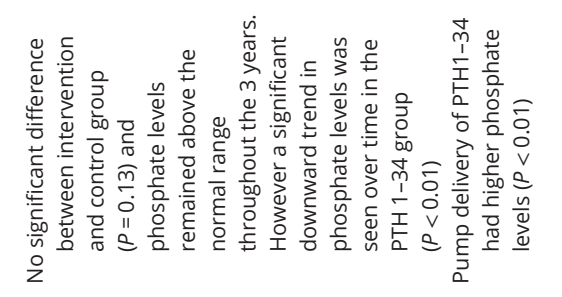

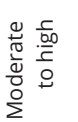
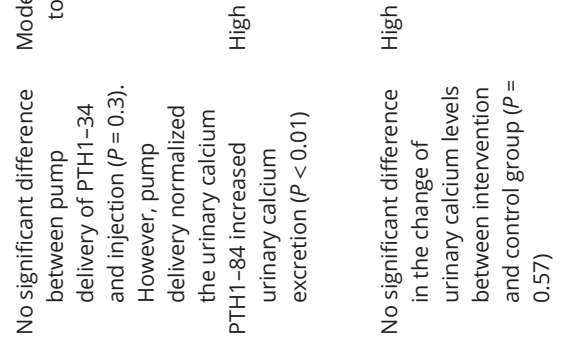

3ิ
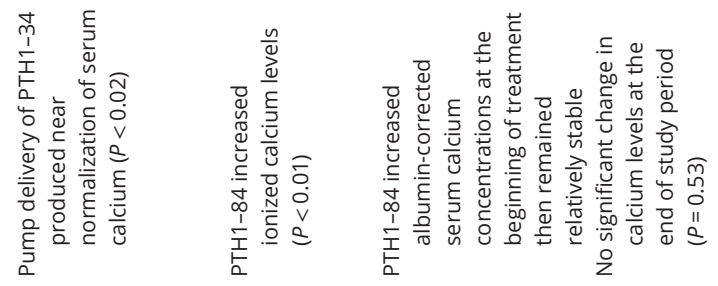

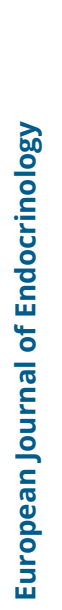
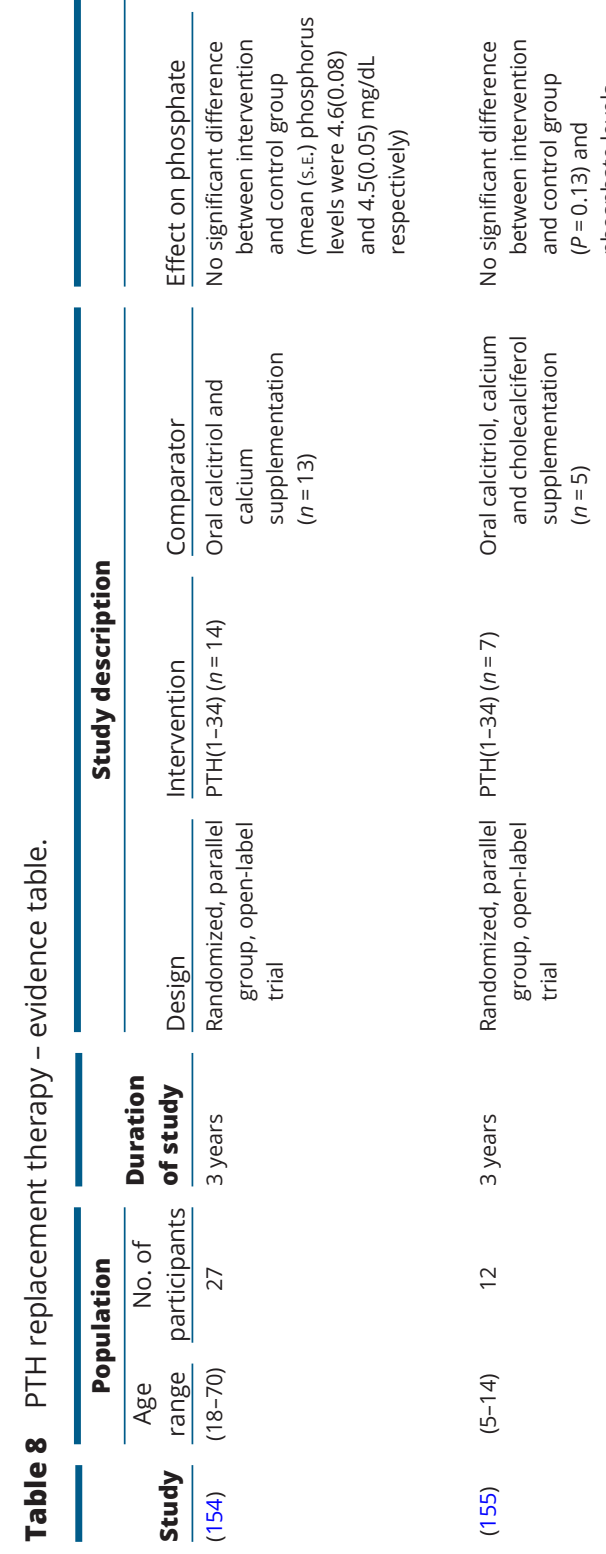

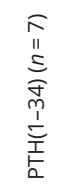
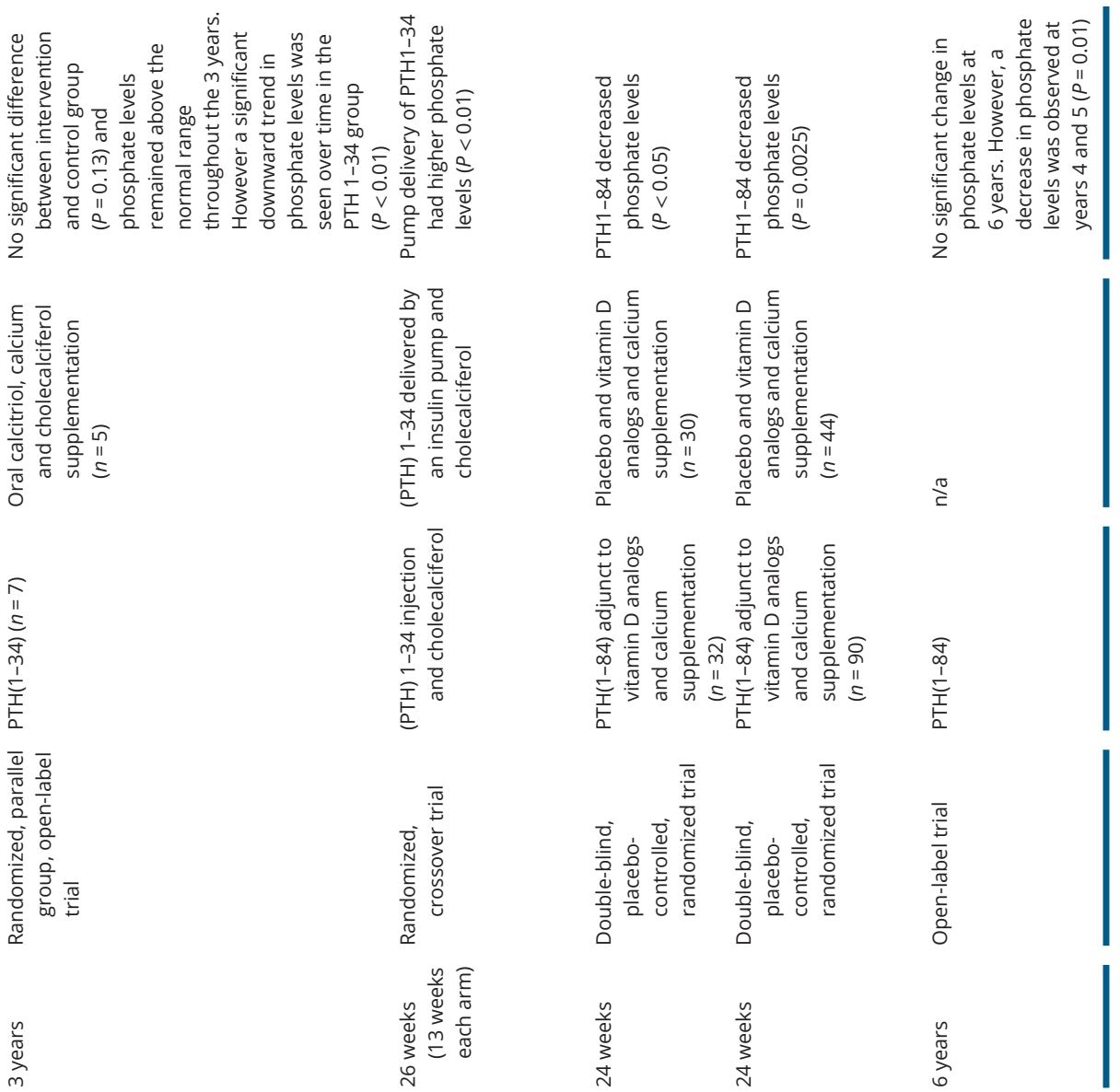

$$
\simeq
$$

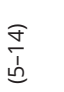

恐

$\stackrel{2}{2}$

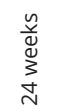

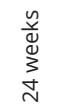

สู

$\stackrel{\text { ț }}{\longrightarrow}$

$\stackrel{\text { a }}{\stackrel{1}{c}}$

$\underset{\substack{\infty \\ \frac{1}{n}}}{\substack{1 \\ 0}}$

$\widehat{1}$
$\infty$
0
$\infty$

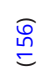

命

o̊

厄ิ 
<smiles>CCCCC</smiles>

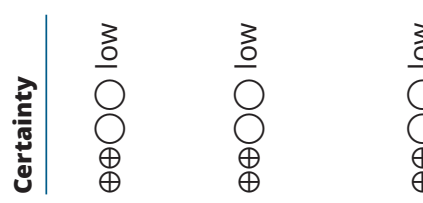

氷

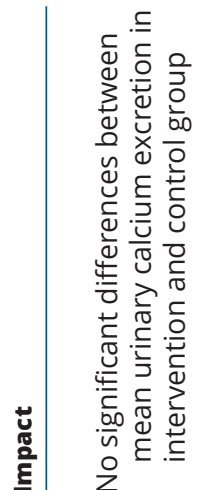

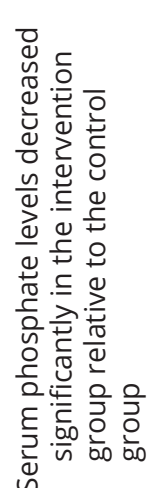

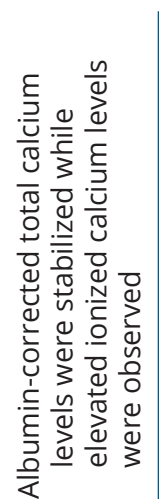

$\frac{0}{2}$

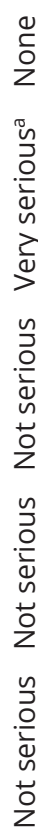

Having such devices easily available to patients will enable assessment of serum calcium with the onset of symptoms and allow closer titration of therapy based on current serum calcium. Such close monitoring is expected to revolutionize care for hypoparathyroidism similar to the enhanced care possible for diabetes with the advent of glucometers. Calcimeters have been developed and are expected to be released for general use in the near future. The approved indications for PTH replacement therapy may vary depending on the regulatory authorities of each country.

\section{Key recommendation:}

rhPTH(1-84) replacement therapy may be considered if the serum calcium is poorly controlled, high doses of calcium or active vitamin $\mathrm{D}$ are required, renal complications are present or quality of life is poor or gastrointestinal malabsorption is present.

Quality of evidence: low.

(c) Once $\mathrm{rhPTH}(1-84)$ replacement therapy is started, how should therapy be titrated?

The FDA approved starting $\operatorname{rhPTH}(1-84)$ at a dose of $50 \mu \mathrm{g}$ by subcutaneous injection once each day with a concomitant $50 \%$ decrease in the dose of active vitamin D metabolites $(83,167)$. After an appropriate interval of several weeks, the dose may be increased to $75 \mu \mathrm{g}$ each day, and then $100 \mu \mathrm{g}$ each day after several more weeks, or reduced to $25 \mu \mathrm{g}$ each day, as required to meet treatment goals, aiming to discontinue the active vitamin $\mathrm{D}$ and reduce calcium supplements to $500 \mathrm{mg}$ daily.

\section{Key recommendation:}

rhPTH(1-84) replacement therapy can be initiated at a $50 \mu \mathrm{g}$ daily dose with close monitoring of serum calcium and phosphate. The dose of rhPTH (1-84) can be gradually titrated upwards or downwards based on the lab profile and the doses of serum calcium and active vitamin D can also be gradually reduced as the dose of the $\operatorname{rhPTH}(1-84)$ is gradually increased.

Quality of evidence: low-moderate.

(d) If $\operatorname{rhPTH}(1-84)$ replacement therapy is initiated, should it ever be stopped?

This is left to the judgment of the treating physician. rhPTH(1-84) replacement therapy may be stopped if treatment goals cannot be achieved despite appropriate dose adjustment, or patients are unable to tolerate or comply with therapy for any reason. Discontinuation of $\operatorname{rhPTH}(1-84)$ requires gradual reductions in the dose over several weeks as abrupt cessation has been associated 
with hypocalcemia, which may reflect increased bone remodeling favoring formation leading to the hungry bone syndrome (168). While decreasing the $\operatorname{rhPTH}(1-84)$ dose treatment with active vitamin $\mathrm{D}$ metabolites should be restarted or adjusted, as appropriate.

\section{Key recommendation:}

Stop therapy if the treatment goals cannot be achieved despite appropriate dose adjustment or if the patient is unable to tolerate or comply with therapy for any reason.

Quality of evidence: low-moderate.

\section{Conclusion}

Hypoparathyroidism is a rare condition, which requires careful evaluation and timely pharmacologic intervention in order to prevent significant morbidity and mortality. Frequent laboratory monitoring of the biochemical profile and patient education is essential to achieving optimal control of serum calcium and potentially lowering the risk of long-term complications.

Pregnancy requires close monitoring to ensure that the mother maintains a serum calcium in the low normal reference range with avoidance of hypercalcemia as well as hypocalcemia for optimal maternal and fetal outcomes.

Conventional therapy consists of calcium and active vitamin D. PTH replacement therapy has been demonstrated to lower the doses of calcium and active vitamin $\mathrm{D}$ required and may lower the long-term complications of hypoparathyroidism.

\section{Declaration of interest}

A K: Research funds from Shire; C K: Novartis Pharma, Advisory Board Consultant, Shire Pharmaceuticals, Principal Investigator, A European Post-Authorisation Observational Study (Registry) of Patients With Chronic Adrenal Insufficiency (Al), Springer Publisher, Royalty Honoraria (Book, Journals), Elsevier Publisher, Royalty Honorarium (Journal); S V U: Relationships with for-profit and not-for-profit interests: Grants/Research support: Novartis, Sanofi, Speakers Bureau/Honoraria: Abbott, Acerus pharmaceuticals, Novartis, Ipsen, Sanofi, Consulting Fees: Pfizer; J-P B: No conflict of interest to declare; J B: No disclosures; M L B: Received honoraria from Amgen, Bruno Farmaceutici, Kyowa Kirin; Academic grants and/or speaker: Abiogen, Alexion, Amgen, Bruno Farmaceutici, Eli Lilly, Kyowa Kirin, MSD, NPS, Servier, Shire, SPA; Consultant: Alexion, Bruno Farmaceutici, Kyowa Kirin, Servier, Shirel; C M: Consultant and speaker for Abiogen-Pharma and SHIRE, Research grant from SHIRE; L R: Speakers fee: Shire, Alexion, Eli Lilly, Amgen, Takeda Pharmaceuticals; Consultancy: Shire, Alexion and Kyowa Kirin; R R: Advisory board or speaker for Radius Health, Sandoz, Effryx and Theramex; M Z S: Grants/Research Support: Eli Lilly, Valeant, Novo Nordisk Speakers Bureau/Honoraria/Consulting Fees: Novo Nordisk, Amgen, Merck; B Y: Nothing to disclose; R T: Research income from: Medical Research Council programme grant, Wellcome Trust Investigator Award, NIHR Senior Investigator, NIHR Translational Research Collaboration, NIHR Oxford Grant - BRC funding, Wellcome Trust clinical training fellowships, EU ITN Marie Curie grant, Glaxo-SmithKline research grant, Kidney Research UK (KRUK) project grant, Novartis Research Grant, NPS Pharmaceuticals (USA), Marshall Smith Syndrome Research Fund. Chairman of Astra-Zeneca Stratified Medicine Panel, Honoraria/lecture and consultancy fees from Novartis, Lilly, AstraZeneca and Ipsen; B C: Research grant support and consultant for Shire, Inc., Data monitoring board member for Amgen, Inc., Data monitoring board member for GSK.

\section{Funding}

Funding was received from Canadian Endocrine Update, McMaster University and Western University for the completion of the literature review -2018.

\section{Acknowledgment}

The authors greatly appreciated the support of Hajar Abu Alrob Health Research Methodology, McMaster University for completing the literature search.

\section{References}

1 Guyatt G, Oxman AD, Akl EA, Kunz R, Vist G, Brozek J, Norris S, Flack-Ytter Y, Glasziou P, Debeer H et al. GRADE guidelines: 1. Introduction - GRADE evidence profiles and summary of findings tables. Journal of Clinical Epidemiology 201164 383-394. (https://doi. org/10.1016/j.jclinepi.2010.04.026)

2 Shoback D. Clinical practice. Hypoparathyroidism. New England Journal of Medicine 2008359 391-403. (https://doi.org/10.1056/ NEJMcp0803050)

3 Bilezikian JP, Khan A, Potts JT, Brandi ML, Clarke BL, Shoback D, Juppner H, D'Amour P, Fox J, Rejnmark L et al. Hypoparathyroidism in the adult: epidemiology, diagnosis, pathophysiology, targetorgan involvement, treatment, and challenges for future research. Journal of Bone and Mineral Research 201110 2317-2337. (https://doi. org/10.1002/jbmr.483)

4 Shoback DM, Bilezikian JP, Costa AG, Dempster D, Dralle H, Khan AA \& Bouillon R. Presentation of hypoparathyroidism: etiologies and clinical features. Journal of Clinical Endocrinology and Metabolism 2016 101 2300-2312. (https://doi.org/10.1210/jc.2015-3909)

5 Mannstadt M, Bilezikian JP, Thakker RV, Hannan FM, Clarke BL, Rejnmark L \& Shoback DM. Hypoparathyroidism. Nature Reviews Disease Primers 20173 17055. (https://doi.org/10.1038/ nrdp.2017.55)

6 Meola A, Vignali E, Matrone A, Cetani F \& Marcocci C. Efficacy and safety of long-term management of patients with chronic postsurgical hypoparathyroidism. Journal of Endocrinological Investigation 201841 1221-1226. (https://doi.org/10.1007/s40618-018-0857-5)

7 Asari R, Passler C, Kaczirek K, Scheuba C \& Niederle B. Hypoparathyroidism after total thyroidectomy a prospective study. Archives of Surgery 2008143 132-137. (https://doi.org/10.1001/ archsurg.2007.55)

8 Edafe O, Antakia R, Laskar N, Uttley L \& Balasubramanian SP. Systematic review and meta-analysis of predictors of postthyroidectomy hypocalcaemia. British Journal of Surgery 2014101 307-320. (https://doi.org/10.1002/bjs.9384)

9 Selberherr A, Scheuba C, Riss P \& Niederle B. Postoperative hypoparathyroidism after thyroidectomy: efficient and cost-effective diagnosis and treatment. Surgery 2015157 349-353. (https://doi. org/10.1016/j.surg.2014.09.007)

10 Lankisch TO, Jaeckel E \& Strassburg CP. The autoimmune polyendocrinopathy-candidiasis-ectodermal dystrophy or autoimmune polyglandular syndrome type 1. Seminars in Liver Disease 200929 307-314. (https://doi.org/10.1055/s-0029-1233535) 
11 Husebye ES, Perheentupa J, Rautemaa R \& Kämpe O. Clinical manifestations and management of patients with autoimmune polyendocrine syndrome type I. Journal of Internal Medicine 2009265 514-529. (https://doi.org/10.1111/j.1365-2796.2009.02090.x)

12 Husebye ES, Anderson M \& Kämpe O. Autoimmune polyendocrine syndromes. New England Journal of Medicine 2018378 1132-1141. (https://doi.org/10.1056/NEJMra1713301)

13 Blizzard RM, Chee D \& Davis W. The incidence of parathyroid and other antibodies in the sera of patients with idiopathic hypoparathyroidism. Clincal and Experimental Immunology 19661 119-128.

14 Zhang J, Liu H, Liu Z, Liao JY, Guo L, Wang H, He L, Zhang X \& Xing Q. A functional alternative splicing mutation in AIRE gene causes autoimmune polyendocrine syndrome type 1. PLOS ONE 2013 8 53981. (https://doi.org/10.1371/journal.pone.0053981)

15 Kifor O, Mcelduff A, Leboff MS, Moore FD, Butters R, Gao P, Cantor TL, Kifor I \& Brown EM. Activating antibodies to the calcium-sensing receptor in two patients with autoimmune hypoparathyroidism. Journal of Clinical Endocrinology and Metabolism 200489 548-556. (https://doi.org/10.1210/jc.2003-031054)

16 Li Y, Song YH, Rais N, Connor YE, Schatz D, Muir A \& Maclaren N. Autoantibodies to the extracellular domain of the calcium sensing receptor in patients with acquired hypoparathyroidism. Journal of Clinical Investigation 199697 910-914. (https://doi.org/10.1172/ JCI118513)

17 Ding C, Buckingham B \& Levine MA. Familial isolated hypoparathyroidism caused by a mutation in the gene for the transcription factor GCMB. Journal of Clinical Investigation 2001108 1215-1220. (https://doi.org/10.1172/JCI200113180)

18 Lienhardt A, Bai M, Jean-Pierre L, Rigaud M, Zhang Z, Jiang Y, Kottler ML, Brown EM \& Garabédian M. Activating mutations of the calcium-sensing receptor: management of hypocalcemia. Journal of Clinical Endocrinology and Metabolism 200186 5313-5323. (https:// doi.org/10.1210/jcem.86.11.8016)

19 Nesbit MA, Hannan FM, Howles SA, Babinsky VN, Head RA, Cranston T, Rust N, Hobbs MR, Heath H \& Thakker RV. Mutations affecting G-protein subunit $\alpha_{11}$ in hypercalcemia and hypocalcemia. New England Journal of Medicine 2013368 2476-2486. (https://doi. org/10.1056/NEJMoa1300253)

20 Roszko KL, Bi RD \& Mannstadt M. Autosomal dominant hypocalcemia (hypoparathyroidism) types 1 and 2. Frontiers in Physiology 20167 458. (https://doi.org/10.3389/fphys.2016.00458)

21 Arnold A, Horst SA, Gardella TJ, Baba H, Levine MA \& Kronenberg HM. Mutation of the signal peptide-encoding region of the preproparathyroid hormone gene in familial isolated hypoparathyroidism. Journal of Clinical Investigation 199086 1084-1087. (https://doi.org/10.1172/JCI114811)

22 Kobrynski LJ \& Sullivan KE. Velocardiofacial syndrome, DiGeorge syndrome: the chromosome 22q11.2 deletion syndromes. Lancet 2007370 1443-1452. (https://doi.org/10.1016/S01406736(07)61601-8)

23 Ryan AK, Goodship JA, Wilson DI, Philip N, Levy A, Seidel H, Schuffenhauer S, Oechsler H, Belohradsky B, Prieur M et al. Spectrum of clinical features associated with interstitial chromosome 22q11 deletions: a European collaborative study. Journal of Medical Genetics 199734 798-804. (https://doi.org/10.1136/jmg.34.10.798)

24 Digilio M, Marino B, Capolino R \& Dallapiccola B. Clinica manifestations of deletion 22q11.2 syndrome (DiGeorge/VeloCardio-Facial syndrome). Images in Pediatric Cardiology 20057 23-34.

25 Muroyaa K, Hasegawaa T, Ito Y, Nagaid T, Isotanie H, Iwat Y, Yamamotoa K, Fujimotog S, Seishuh S, Fukushima Y et al. GATA3 abnormalities and the phenotypic spectrum of HDR syndrome. Journal of Medical Genetics 200138 374-380. (https://doi. org/10.1136/jmg.38.6.374)

26 Sepahi MA, Baraty B \& Shooshtary FK. HDR syndrome (hypoparathyroidism, sensorineural deafness and renal disease) accompanied by hirschsprung disease. Iranian Journal of Pediatrics 201020 23-126.

27 Sanjad SA, Sakati NA, Abu-Osba YK, Kaddoura R \& Milner RD. A new syndrome of congenital hypoparathyroidism. Archives of Disease in Childhood 199166 193-196. (https://doi.org/10.1136/adc.66.2.193)

28 Khan KTS, Uma R, Usha R, Al-Ghanem MM, Al-Awadi SA \& Farag TI. Kenny-Caffey syndrome in six Bedouin sibships: autosomal recessive inheritance is confirmed. American Journal of Medical Genetics 199769 126-132. (https://doi.org/10.1002/(SICI)10968628(19970317)69:2<126::AID-AJMG3>3.0.CO;2-N)

29 Kelly T, Blanton S, Saif R, Sanjad S \& Sakati N. Confirmation of the assignment of the Sanjad-Sakati (congenital hypoparathyroidism) syndrome (OMIM 241410) locus to chromosome lq42-43. Journal of Medical Genetics 200037 63-64. (https://doi.org/10.1136/ jmg.37.1.63

30 Brinkane A, Peschard S, Leroy-Terquem E, Bergheul S, Raheriarisoa H, Hubert N, Crickx L \& Levy R. Rare association of hypoparathyroidism and mediastinal-pulmonary sarcoidosis. Annales de Medecine Interne 2001152 63-64.

31 Saeed A, Khan M, Irwin S \& Fraser A. Sarcoidosis presenting with severe hypocalcaemia. Irish Journal of Medical Science 2011180 575-577. (https://doi.org/10.1007/s11845-009-0277-9)

32 Badell A, Servitje O, Graells J, Vidaller A \& Peyri J. Hypoparathyroidism and sarcoidosis. British Journal of Dermatology 1998138 915-917. (https://doi.org/10.1046/j.13652133.1998.02244.x)

33 Anderson TJ \& Ewen SWB. Amyloid in normal and pathological parathyroid glands. Journal of Clinical Pathology 197427 656-663. (https://doi.org/10.1136/jcp.27.8.656)

34 Yasmeen T, Khan S, Patel SG, Reeves WA, Gonsch FA, De Bustros A \& Kaplan EL. Riedel's thyroiditis: report of a case complicated by spontaneous hypoparathyroidism, recurrent laryngeal nerve injury, and Horner's syndrome. Journal of Clinical Endocrinology and Metabolism 200287 3543-3547. (https://doi.org/10.1210/ jcem.87.8.8752)

35 Horwitz CA, Myers WL \& Foote FW. Secondary malignant tumors of the parathyroid glands: report of two cases with associated hypoparathyroidism. American Journal of Medicine 197252 797-808. (https://doi.org/10.1016/0002-9343(72)90086-1)

36 Glazebrook GA. Effect of decicurie doses of radioactive iodine 131 on parathyroid function. American Journal of Surgery 1987 154 368-373. (https://doi.org/10.1016/0002-9610(89)90006-8)

37 Winslow CP \& Meyers AD. Hypocalcemia as a complication of radioiodine therapy. American Journal of Otolaryngology 199819 401-403. (https://doi.org/10.1016/S0196-0709(98)90045-X)

38 Guven A, Salman S, Boztepe H, Yarman S, Tanakol R, Azizlerli H \& Alagol F. Parathyroid changes after high dose radioactive iodine in patients with thyroid cancer. Annals of Nuclear Medicine 200923 437-441. (https://doi.org/10.1007/s12149-009-0270-4)

39 Carpenter T, Carnes DJ \& Anast C. Hypoparathyroidism in Wilson's disease. New England Journal of Medicine 1983309 873-877. (https:// doi.org/10.1056/NEJM198310133091501)

40 Fatima J, Karoli R \& Jain V. Hypoparathyroidism in a case of Wilson's disease: rare association of a rare disorder. Indian Journal of Endocrinology and Metabolism 201317 361-362. (https://doi. org/10.4103/2230-8210.109689)

41 Okada M, Higashi K, Enomoto S, Fujii Y, Yamane H, Tsujiuti K, Tanimoto S, Itoh H, Nishioka S, Yasui M \& Tanaka T. A case of Wilson's disease associated with hypoparathyroidism and amenorrhea. Nihon Shokakibyo Gakkai Zasshi 199895 445-449.

42 Belhoul KM, Bakir ML, Saned MS, Kadhim AM, Musallam KM \& Taher AT. Serum ferritin levels and endocrinopathy in medically treated patients with B thalassemia major. Annals of Hematology 2012 91 1107-1114. (https://doi.org/10.1007/s00277-012-1412-7)

43 Angelopoulos N, Goula A, Rombopoulos G, Kaltzidou V, Katounda E, Kaltsas D \& Tolis G. Hypoparathyroidism in transfusion-dependent 
patients with beta-thalassemia. Journal of Bone and Mineral Metabolism 200624 138-145. (https://doi.org/10.1007/s00774-005-0660-1)

44 Aleem A, Al-Momen A, Al-Harakati M, Hassan A \& Al-Fawaz I. Hypocalcemia due to hypoparathyroidism in beta-thalassemia major patients. Annals of Saudi Medicine 200020 364-366. (https://doi. org/10.5144/0256-4947.2000.364)

45 Klein G, Nicolai M, Langman C, Cuneo B, Sailer D \& Herndon D. Dysregulation of calcium homeostasis after severe burn injury in children: possible role of magnesium depletion. Journal of Pediatrics 1997131 246-251. (https://doi.org/10.1016/S00223476(97)70161-6)

46 Klein GL. Burns: where has all the calcium (and vitamin D) gone? Advances in Nutrition 20112 457-462. (https://doi.org/10.3945/ an.111.000745)

47 Steen O \& Khan AA. Role of magnesium in parathyroid physiology. In Hypoparathyroidism, pp 61-67. Eds ML Brandi \& EM Brown. New York, NY: Springer, 2015.

48 Khan AA, Sbayi A \& Schlingmann KP. Magnesium Homeostasis. In Primer on the metabolic bone diseases and disorders of mineral metabolism, edn 9, Ch. 23. Eds John P Bilezikian. John Wiley \& Sons Inc., 2019

49 Vetter T \& Lohse M. Magnesium and the parathyroid. Current Opinion in Nephrology and Hypertension 200211 403-410. (https://doi. org/10.1097/00041552-200207000-00006)

50 Grubbs R \& Maguire M. Magnesium as a regulatory cation: criteria and evaluation. Magnesium 19876 113-127.

51 Chang W, Pratt S, Chen T, Nemeth E, Huang Z \& Shoback D. Coupling of calcium receptors to inositol phosphate and cyclic AMP generation in mammalian cells and Xenopus laevis oocytes and immunodetection of receptor protein by region-specific antipeptide antisera. Journal of Bone and Mineral Research 199813 570-580. (https://doi.org/10.1359/jbmr.1998.13.4.570)

52 Pearce S, Williamson C, Kifor O, Bai M, Coulthard M, Davies M, Lewis-Barned N, McCredie D, Powell H, Kendall-Taylor P et al. A familial syndrome of hypocalcemia with hypercalciuria due to mutations in the calcium-sensing receptor. New England Journal of Medicine 1996335 1115-1122. (https://doi.org/10.1056/ NEJM199610103351505)

53 Weber S, Schneider L, Peters M, Misselwitz J, Ronnefarth G, Boswald M, Bonzel K, Seeman T, Suláková T, Kuwertz-Bröking E et al. Novel paracellin-1 mutations in 25 families with familial hypomagnesemia with hypercalciuria and nephrocalcinosis. Journal of the American Society of Nephrology 200112 1872-1881.

54 Konrad M, Hou J, Weber S, Dotsch J, Kari J, Seeman T, KuwertzBröking E, Peco-Antic A, Tasic V, Dittrich K et al. CLDN16 genotype predicts renal decline in familial hypomagnesemia with hypercalciuria and nephrocalcinosis. Journal of the American Society of Nephrology 200819 171-181. (https://doi.org/10.1681/ ASN.2007060709)

55 Schlingmann K, Weber S, Peters M, Neimann N, Vitzthum H, Klingel K, Kratz M, Haddad E, Ristoff E, Dinour D et al. Hypomagnesemia with secondary hypocalcemia is caused by mutations in TRPM6, a new member of the TRPM gene family. Nature Genetics 200231 166-170. (https://doi.org/10.1038/ng889)

56 Walder R, Landau D, Meyer P, Shalev H, Tsolia M, Borochowitz Z, Boettger M, Beck G, Englehardt R, Carmi R \& Sheffield V. Mutation of TRPM6 causes familial hypomagnesemia with secondary hypocalcemia. Nature Genetics 200231 71-174. (https://doi. org/10.1038/ng901)

57 Quitterer U, Hoffmann M, Friechel M \& Lohse M. Paradoxical block of parathormone secretion is mediated by increased activity of $\mathrm{G}$ alpha subunits. Journal of Biological Chemistry 2001276 6763-6769. (https://doi.org/10.1074/jbc.M007727200)

58 Elisaf M, Panteli K, Theodorou J \& Siamopoulos KC. Fractional excretion of magnesium in normal subjects and in patients with hypomagnesemia. Magnesium Research 199710 315-320.
59 Zupanc M, Moraes C, Shanske S, Langman C, Ciafaloni E \& DiMauro S. Deletion of mitochondrial DNA in patients with combined features of Kearns-Sayre and MELAS syndromes. Annals of Neurology 199129 680-683. (https://doi.org/10.1002/ana.410290619)

60 Dionisi-Vici C, Garavaglia B, Burlina AB, Bertini E, Saponara I, Sabetta G \& Taroni F. Hypoparathyroidism in mitochondrial trifunctional protein deficiency. Journal of Pediatrics 1996129 159-162. (https://doi.org/10.1016/S0022-3476(96)70206-8)

61 Ya H, Ming C, Zhengyi S, Zhe S, Xiang G, Quan L \& Yupei Z. Clinical presentation, management, and outcomes of primary hyperparathyroidism during pregnancy. International Journal of Endocrinology 20172017 3947423. (https://doi. org $/ 10.1155 / 2017 / 3947423)$

62 Truong MT, Lalakea ML, Robbins P \& Friduss M. Primary hyperparathyroidism in pregnancy: a case series and review. Laryngoscope 2008118 1966-1969. (https://doi.org/10.1097/ MLG.0b013e318180276f)

63 Schnatz P \& Curry S. Primary hyperparathyroidism in pregnancy: evidence-based management. Obstetrical Gynecological Survey 200257 365-376. (https://doi.org/10.1097/00006254-200206000-00022)

64 Spiegel AM, Weinstein LS \& Shenker A. Abnormalities in G proteincoupled signal transduction pathways in human disease. Journal of Clinical Investigation 199392 1119-1125. (https://doi.org/10.1172/ JCI116680)

65 Hayward BE, Kamiya M, Strain L, Moran V, Campbell R, Hayas Y \& Bonthron DT. The human GNAS1 gene is imprinted and encodes distinct paternally and biallelically expressed G proteins. PNAS 1998 95 10038-10043. (https://doi.org/10.1073/pnas.95.17.10038)

66 Albright F, Burnett C, Smith P \& Parson W. Pseudohypoparathyroidism - an example of Seabright-Bantam syndrome': report of three cases. Endocrinology Journal 194230 922-932.

67 Levine MA, Downs RW, Moses AM, Breslau NA, Marx SJ, Lasker RD, Rizzoli RE, Aurbach GD \& Spiegel AM. Resistance to multiple hormones in patients with pseudohypoparathyroidism. Association with deficient activity of guanine nucleotide regulatory protein American Journal of Medicine $1983 \mathbf{7 4}$ 545-556. (https://doi. org/10.1016/0002-9343(83)91008-2)

68 Bastepe M, Fröhlich L, Hendy G, Indridason O, Josse R, Koshiyama H, Körkkö J, Nakamoto J, Rosenbloom A, Slyper A et al. Autosomal dominant pseudohypoparathyroidism type $\mathrm{Ib}$ is associated with a heterozygous microdeletion that likely disrupts a putative imprinting control element of GNAS. Journal of Clinical Investigation 2003112 1255-1263. (https://doi.org/10.1172/ JCI19159)

69 Murray T, Rao L, Wong M, Waddell J, McBroom R, Tam C, Rosen F \& Levine M. Pseudohypoparathyroidism with osteitis fibrosa cystica: direct demonstration of skeletal responsiveness to parathyroid hormone in cells cultured from bone. Journal of Bone and Mineral Research 19938 83-91. (https://doi.org/10.1002/jbmr.5650080111)

70 Farfel Z, Brothers VM, Brickman AS, Conte F, Neer R \& Bourne HR. Pseudohypoparathyroidism: Inheritance of deficient receptor cyclase coupling activity. PNAS 198178 3098-3102. (https://doi. org/10.1073/pnas.78.5.3098)

71 Mantovani G, Maghnie M, Weber G, De Menis E, Brunelli V, Cappa M, Loli P, Beck-Peccoz P \& Spada A. Growth hormonereleasing hormone resistance in pseudohypoparathyroidism type Ia: new evidence for imprinting of the Gs alpha gene. Journal of Clinical Endocrinology and Metabolism 200388 4070-4074. (https://doi. org/10.1210/jc.2002-022028)

72 Shore E, Ahn J, Jan de Beur S, Li M, Xu M, Gardner R, Zasloff M, Whyte M, Levine M \& Kaplan F. Paternally inherited inactivating mutations of the GNAS1 gene in progressive osseous heteroplasia. New England Journal of Medicine 2002346 99-106. (https://doi. org/10.1056/NEJMoa011262)

73 Bollerslev J, Rejnmark L, Marcocci C, Shoback DM, Sitges-Serra A, Van Biesen W \& Dekkers OM. European Society of Endocrinology 
Clinical Guideline: treatment of chronic hypoparathyroidism in adults. European Journal of Endocrinology 2015173 G1-G20. (https:// doi.org/10.1530/EJE-15-0628)

74 Brandi ML, Bilezikian JP, Shoback D, Bouillon R, Clarke BL, Thakker RV, Khan AA \& Potts JT. Management of hypoparathyroidism: summary statement and guidelines. Journal of Clinical Endocrinology and Metabolism 2016101 2273-2283. (https:// doi.org/10.1210/jc.2015-3907)

75 Mitchell DM, Regan S, Cooley MR, Lauter KB, Vrla MC, Becker CB \& Mannstadt M. Long-term follow-up of patients with hypoparathyroidism. Journal of Clinical Endocrinology and Metabolism 201297 4507-4514. (https://doi.org/10.1210/jc.2012-1808)

76 Boyce AM, Shawker TH, Hill SC, Choyke PL, Hill MC, James R, Yovetich NA, Collins MT \& Gafni RI. Ultrasound is superior to computed tomography for assessment of medullary nephrocalcinosis in hypoparathyroidism. Journal of Clinical Endocrinology and Metabolism 201398 989-994. (https://doi.org/10.1210/jc.2012-2747)

77 Smith-Bindman R, Aubin C, Bailitz J, Bengiamin RN, Camargo CA, Corbo J, Dean AJ, Goldstein RB, Griffey RT, Jay GD et al. Ultrasonography versus computed tomography for suspected nephrolithiasis. New England Journal of Medicine 201437112. (https://doi.org/10.1056/NEJMicm1312048)

78 Underbjerg L, Sikjaer T, Mosekilde L \& Rejnmark L. Cardiovascular and renal complications to postsurgical hypoparathyroidism: a Danish nationwide controlled historic follow-up study. Journal of Bone and Mineral Research 201328 2277-2285. (https://doi. org/10.1002/jbmr.1979)

79 Underbjerg L, Sikjaer T, Mosekilde L \& Rejnmark L. The epidemiology of nonsurgical hypoparathyroidism in Denmark: a nationwide case finding study. Journal of Bone and Mineral Research 201530 1738-1744. (https://doi.org/10.1002/jbmr.2501)

80 Arlt W, Fremerey C, Callies F, Reincke M, Schneider P, Timmermann W \& Allolio B. Well-being, mood and calcium homeostasis in patients with hypoparathyroidism receiving standard treatment with calcium and vitamin D. European Journal of Endocrinology 2002146 215-222. (https://doi.org/10.1530/ eje.0.1460215)

81 Chawla H, Saha S, Kandasamy D, Sharma R, Sreenivas V \& Goswami R. Vertebral fractures and bone mineral density in patients with idiopathic hypoparathyroidism on long-term follow-up. Journa of Clinical Endocrinology and Metabolism 2017102 251-258. (https:// doi.org/10.1210/jc.2016-3292)

82 Goswami R, Sharma R, Sreenivas V, Gupta N, Ganapathy A \& Das S. Prevalence and progression of basal ganglia calcification and its pathogenic mechanism in patients with idiopathic hypoparathyroidism. Clinical Endocrinology 201277 200-206. (https://doi.org/10.1111/j.1365-2265.2012.04353.x)

83 Bilezikian JP, Brandi ML, Cusano NE, Mannstadt M, Rejnmark L, Rizzoli R \& Potts JT. Management of hypoparathyroidism: present and future. Journal of Clinical Endocrinology and Metabolism 2016101 2313-2324. (https://doi.org/10.1210/jc.2015-3910)

84 Underbjerg L, Sikjaer T \& Rejnmark L. Long-term complications in patients with hypoparathyroidism evaluated by biochemical findings: a case-control study. Journal of Bone and Minernal Research 201833 822-831. (https://doi.org/10.1002/jbmr.3368)

85 Astor MC, Løvås K, Debowska A, Eriksen EF, Evang JA, Fossum C, Fougner KJ, Holte SE, Lima K, Moe RB et al. Epidemiology and health-related quality of life in hypoparathyroidism in Norway. Journal of Clinical Endocrinology and Metabolism 2016101 3045-3053. (https://doi.org/10.1210/jc.2016-1477)

86 Al-Azem H \& Khan AA. Hypoparathyroidism. Best Practice and Research: Clinical Endocrinology and Metabolism 201226 517-22. (https://doi.org/10.1016/j.beem.2012.1101.004)

87 Anast CS, Mohs JM, Kaplan SL \& Burns TW. Evidence for parathyroid failure in magnesium deficiency. Science 1972177 606-608. (https:// doi.org/10.1126/science.177.4049.606)
88 Groenestege WM, Thebault S, Van der Wijst J, Van den Berg D, Janssen R, Tejpar S, Can De Heuvel LP, Van Custem E, Hoenderop JG et al. Impaired basolateral sorting of pro-EGF causes isolated recessive renal hypomagnesemia. Journal of Clinical Investigation $2007 \mathbf{1 1 7}$ 2260-2267. (https://doi.org/10.1172/JCI31680)

89 Hoorn EJ, Walsh SB, McCormick JA, Furstenberg A, Yang CL, Roeschel T, Paliege A, Howie AJ, Conley J, Bachmann S et al. The calcineurin inhibitor tacrolimus activates the renal sodium chloride cotransporter to cause hypertension. Nature Medicine 201117 1304-1309. (https://doi.org/10.1038/nm.2497)

90 Nijenhuis T, Vallon V, Van der Kemp AW, Loffing J, Hoenderop JG \& Bindels RJ. Enhanced passive $\mathrm{Ca} 2+$ reabsorption and reduced $\mathrm{Mg} 2+$ channel abundance explains thiazide-induced hypocalciuria and hypomagnesemia. Journal of Clinical Investigation $2005 \mathbf{1 1 5}$ 1651-1658. (https://doi.org/10.1172/JCI24134)

91 Mune T, Yasuda K, Ishii M, Matsunaga T \& Miura K. Tetany due to hypomagnesemia induced by cisplatin and doxorubicin treatment for synovial sarcoma. Internal Medicine 199332 434-437. (https://doi. org/10.2169/internalmedicine.32.434)

92 Mori S, Harada S, Okazaki R, Inoue D, Matsumoto T \& Ogata E. Hypomagnesemia with increased metabolism of parathyroid hormone and reduced responsiveness to calcitropic hormones. Internal Medicine 199231 820-824. (https://doi.org/10.2169/ internalmedicine.31.820)

93 Mihara M, Kamikubo K, Hiramatsu K, Itaya S, Ogawa T \& Sakata S. Renal refractoriness to phosphaturic action of parathyroid hormone in a patient with hypomagnesemia. Internal Medicine 199534 666-669. (https://doi.org/10.2169/internalmedicine.34.666)

94 Ballane GT, Sfeir JG, Dakik HA, Brown EM \& El-Hajj Fuleihan G. Use of recombinant human parathyroid hormone in hypocalcemic cardiomyopathy. European Journal of Endocrinology 2012166 1113-1120. (https://doi.org/10.1530/EJE-11-1094)

95 Cho YH, Tchan M, Roy B, Halliday R, Wilson M, Dutt S, Siew S, Munns C \& Howard N. Recombinant parathyroid hormone therapy for severe neonatal hypoparathyroidism. Journal of Pediatrics 2012 160 345-348. (https://doi.org/10.1016/j.jpeds.2011.09.022)

96 Puig-Domingo M, Díaz G, Nicolau J, Fernández C, Rueda S \& Halperin I. Successful treatment of vitamin D unresponsive hypoparathyroidism with multiple subcutaneous infusion of teriparatide. European Journal of Endocrinology 2008159 653-657. (https://doi.org/10.1530/EJE-08-0269)

97 Kooh SW, Fraser D, DeLuca HF, Holick MF, Belsey RE, Clark MB \& Murray TM. Treatment of hypoparathyroidism and pseudohypoparathyroidism with metabolites of vitamin D: evidence for impaired conversion of 25-hydroxyvitamin D to 1 alpha,25dihydroxyvitamin D. New England Journal of Medicine 1975293 840-844. (https://doi.org/10.1056/NEJM197510232931702)

98 Neer RM, Holick MF, DeLuca HF \& Potts JT. Effects of 10-hydroxyvitamin D3 and 1,25-dihydroxyvitamin D3 on calcium and phosphorus metabolism in hypoparathyroidism. Metabolism 197524 1403-1413. (https://doi.org/10.1016/0026-0495(75)90055-4)

99 Halabe A, Arie R, Mimran D, Samuel R \& Liberman UA. Hypoparathyroidism - a long-term follow-up experience with 1 alpha-vitamin D3 therapy. Clinical Endocrinology 199440 303-307. (https://doi.org/10.1111/j.1365-2265.1994.tb03923.x)

100 Holick MF, Biancuzzo RM, Chen TC, Klein EK, Young A, Bibuld D, Reitz R, Salameh W, Ameri A \& Tannenbaum AD. Vitamin D2 is as effective as vitamin D3 in maintaining circulating concentrations of 25-hydroxyvitamin D. Journal of Clinical Endocrinology Metabolism 200893 677-681. (https://doi.org/10.1210/jc.2007-2308)

101 Porter RH, Cox BG, Heaney D, Hostetter TH, Stinebaugh BJ \& Suki WN. Treatment of hypoparathyroid patients with chlorthalidone. New England Journal of Medicine 1978298 577-581. (https://doi.org/10.1056/NEJM197803162981101)

102 Kovacs CS. Maternal mineral and bone metabolism during pregnancy, lactation, and post-weaning recovery. Physiological 
Reviews 201696 449-547. (https://doi.org/10.1152/ physrev.00027.2015)

103 Kovacs CS. Calcium, phosphorus, and bone metabolism in the fetus and newborn. Early Human Development 201591 623-628. (https:// doi.org/10.1016/j.earlhumdev.2015.08.007)

104 Pitkin RM \& Gebhardt MP. Serum calcium concentrations in human pregnancy. American Journal of Obstetrics and Gynecology 1977127 775-778. (https://doi.org/10.1016/0002-9378(77)90256-3)

105 Dahlman T, Sjoberg HE \& Bucht E. Calcium homeostasis in normal pregnancy and puerperium. A longitudinal study. Acta Obstetricia et Gynecologica Scandinavica 199473 393-398. (https://doi. org/10.3109/00016349409006250)

106 Ardawi SM, Nasrat HA \& BA'Aqueel HS. Calcium-regulating hormones and parathyroid hormone-related peptide in normal human pregnancy and postpartum: a longitudinal study. European Journal of Endocrinology 1997137 402-409. (https://doi.org/10.1530/ eje.0.1370402)

107 Bertelloni S, Baroncelli GI, Pelletti A, Battini R \& Saggese G. Parathyroid hormone-related protein in healthy pregnant women. Calcified Tissue International 199454 195-197. (https://doi. org/10.1007/BF00301677)

108 Gallacher SJ, Fraser WD, Owens OJ, Dryburgh FJ, Logue FC, Jenkins A, Kenndy J \& Boyle IT. Changes in calciotrophic hormones and biochemical markers of bone turnover in normal human pregnancy. European Journal of Endocrinology 1994131 369-374. (https://doi.org/10.1530/eje.0.1310369)

109 Yadav S, Goel MM, Singh U, Natu SM \& Negi MPS. Calcitonin gene- and parathyroid hormone-related peptides in normotensive and preeclamptic pregnancies: a nested case-control study. Archives of Gynecology and Obstetrics 2014290 897-903. (https://doi. org/10.1007/s00404-014-3303-8)

110 Asa SL, Henderson J, Goltzman D \& Drucker DJ. Parathyroid hormone-like peptide in normal and neoplastic human endocrine tissues. Journal of Clinical Endocrinology and Metabolism $19907 \mathbf{1}$ 1112-1118. (https://doi.org/10.1210/jcem-71-5-1112)

111 Danks JA, Ebeling PR, Hayman JA, Diefenbach-Jagger H, Collier FM, Grill V, Southby J, Moseley JM, Chou ST \& Martin TJ. Immunohistochemical localization of parathyroid hormone-related protein in parathyroid adenoma and hyperplasia. Journal of Pathology 1990161 27-33. (https://doi.org/10.1002/path.1711610106)

112 Ikeda K, Weir EC, Mangin M, Dannies PS, Kinder B, Deftos LJ, Brown E \& Broadus AE. Expression of messenger ribonucleic acids encoding a parathyroid hormone-like peptide in normal human and animal tissues with abnormal expression in human parathyroid adenomas. Molecular Endocrinology 19882 1230-1236. (https://doi. org/10.1210/mend-2-12-1230)

113 Wittelsberger A \& Rosenblatt M. Parathyroid hormone-receptor interactions. In Principles of Bone Biology, 3rd ed., pp 595-637. Eds JP Bilezikian, LG Raisz \& TJ Martin. New York: Academic, 2008.

114 Caplan RH, Miller CD \& Silva PD. Severe hypercalcemia in a lactating woman in association with moderate calcium carbonate supplementation: a case report. Journal of Reproductive Medicine 2004 49 214-217.

115 Caplan RH \& Wickus GG. Reduced calcitriol requirements for treating hypoparathyroidism during lactation. A case report. Journal of Reproductive Medicine 199338 914-918.

116 Seely EW, Brown EM, DeMaggio DM, Weldon DK \& Graves SW. A prospective study of calciotropic hormones in pregnancy and post partum: reciprocal changes in serum intact parathyroid hormone and 1,25-dihydroxyvitamin D. American Journal of Obstetrics and Gynecology 1997176 214-217. (https://doi.org/10.1016/S00029378(97)80039-7)

117 Seki K, Makimura N, Mitsui C, Hirata J \& Nagata I. Calciumregulating hormones and osteocalcin levels during pregnancy: a longitudinal study. American Journal of Obstetrics and Gynecology 1991 164 1248-1252. (https://doi.org/10.1016/0002-9378(91)90694-M)
118 Ritchie LD, Fung EB, Halloran BP, Turnlund JR, Van Loan MD, Cann CE \& King JC. A longitudinal study of calcium homeostasis during human pregnancy and lactation and after resumption of menses. American Journal of Clinical Nutrition 199867 693-701. (https://doi.org/10.1093/ajcn/67.4.693)

119 Verhaeghe J \& Bouillon R. Calciotropic hormones during reproduction. Journal of Steroid Biochemistry and Molecular Biology 199241 469-477. (https://doi.org/10.1016/0960-0760(92)90372-P)

120 Wilson SG, Retallack RW, Kent JC, Worth GK \& Gutteridge DH. Serum free 1,25-dihydroxyvitamin $\mathrm{D}$ and the free 1,25-dihydroxyvitamin $\mathrm{D}$ index during a longitudinal study of human pregnancy and lactation. Clinical Endocrinology 199032 613-622. (https://doi.org/10.1111/j.1365-2265.1990.tb00905.x)

121 Kirby BJ, Ma Y, Martin HM, Buckle Favaro KL, Karaplis AC \& Kovacs CS. Upregulation of calcitriol during pregnancy and skeletal recovery after lactation do not require parathyroid hormone. Journal of Bone and Mineral Research 201328 1987-2000. (https://doi. org/10.1002/jbmr.1925)

122 Turner M, Barré P, Benjamin A, Goltzman D \& Gascon-Barré M. Does the maternal kidney contribute to the increased circulating 1,25-dihydroxyvitamin D concentrations during pregnancy? Mineral and Electrolyte Metabolism 198814 246-252.

123 Horwitz MJ, Tedesco MB, Sereika SM, Syed MA, Garcia-Ocaña A, Bisello A, Hollis B, Rosen C, Wysolmerski J, Dann P et al. Continuous PTH and PTHrP infusion causes suppression of bone formation and discordant effects on 1,25(OH)2 vitamin D. Journal of Bone and Mineral Research 200520 1792-1803. (https://doi.org/10.1359/ JBMR.050602)

124 Bikle DD, Gee E, Halloran B \& Haddad JG. Free 1,25-dihydroxyvitamin D levels in serum from normal subjects, pregnant subjects, and subjects with liver disease. Journal of Clinical Investigation 198474 1966-1971. (https://doi.org/10.1172/ JCI111617)

125 Cross NA, Hillman LS, Allen SH, Krause GF \& Vieira NE. Calcium homeostasis and bone metabolism during pregnancy, lactation, and postweaning - a longitudinal-study. American Journal of Clinical Nutrition 199561 514-523. (https://doi.org/10.1093/ajcn/61.3.514)

126 Moller UK, Streym S, Mosekilde L, Heickendorff L, Flyvbjerg A, Frystyk J, Jensen LT \& Rejnmark L. Changes in calcitropic hormones, bone markers and insulin-like growth factor I (IGF-I) during pregnancy and postpartum: a controlled cohort study. Osteoporosis International 201324 1307-1320. (https://doi.org/10.1007/s00198012-2062-2)

127 Carneiro RM, Prebehalla L, Tedesco MB, Sereika SM, Gundberg CM, Stewart AF \& Horwitz MJ. Evaluation of markers of bone turnover during lactation in African-Americans: a comparison with caucasian lactation. Journal of Clinical Endocrinology and Metabolism 201398 523-532. (https://doi.org/10.1210/jc.2012-2118)

128 Carneiro RM, Prebehalla L, Tedesco MB, Sereika SM, Hugo M, Hollis BW, Gundberg CM, Stewart AF \& Horwitz MJ. Lactation and bone turnover: a conundrum of marked bone loss in the setting of coupled bone turnover. Journal of Clinical Endocrinology and Metabolism 201095 1767-1776. (https://doi.org/10.1210/jc.20091518)

129 Schoenmakers I, Jarjou LMA, Goldberg GR, Tsoi K, Harnpanich D \& Prentice A. Acute response to oral calcium loading in pregnant and lactating women with a low calcium intake: a pilot study. Osteoporosis International 201324 2301-2308. (https://doi.org/10.1007/s00198013-2280-2)

130 Roth DE, Morris SK, Zlotkin S, Gernand AD, Ahmed T, Shanta SS, Papp E, Korsiak J, Shi J, Islam MM et al. Vitamin D supplementation in pregnancy and lactation and infant growth. New England Journal of Medicine 2018379 535-546. (https://doi.org/10.1056/ NEJMoa1800927)

131 Black AJ, Topping J, Durham B, Farquharson RG \& Fraser WD. A detailed assessment of alterations in bone turnover, calcium 
homeostasis, and bone density in normal pregnancy. Journal of Bone Mineral Research 200015 557-563. (https://doi.org/10.1359/ jbmr.2000.15.3.557)

132 Rasmussen N, Frolich A, Hornnes PJ \& Hegedüs L. Serum ionized calcium and intact parathyroid hormone levels during pregnancy and postpartum. BJOG: An International Journal of Obstetrics and Gynaecology 199097 857-862. (https://doi. org/10.1111/j.1471-0528.1990.tb02585.x)

133 Frolich A, Rudnicki M, Fischer-Rasmussen W \& Olofsson K. Serum concentrations of intact parathyroid hormone during late human pregnancy: a longitudinal study. European Journal of Obstetrics and Gynecology and Reproductive Biology 199142 85-87. (https://doi. org/10.1016/0028-2243(91)90166-I)

134 Dobnig H, Kainer F, Stepan V, Winter R, Lipp R, Schaffer M, Kahr A, Nocnik S, Patterer G \& Leb G. Elevated parathyroid hormone-related peptide levels after human gestation: relationship to changes in bone and mineral metabolism. Journal of Clinical Endocrinology and Metabolism 199580 3699-3707. (https://doi.org/10.1210/ jcem.80.12.8530622)

135 Kovacs CS \& Chik CL. Hyperprolactinemia caused by lactation and pituitary adenomas is associated with altered serum calcium phosphate parathyroid hormone (PTH) and PTH-related peptide levels. Journal of Clinical Endocrinology and Metabolism 199580 3036-3042. (https://doi.org/10.1210/jcem.80.10.7559893)

136 Lippuner K, Zehnder HJ, Casez JP, Takkinen R \& Jaeger P. PTH-related protein is released into the mother's bloodstream during lactation: evidence for beneficial effects on maternal calcium-phosphate metabolism. Journal of Bone and Mineral Research 199611 1394-1399. (https://doi.org/10.1002/jbmr.5650111004)

137 Balabanova S, Kruse B \& Wolf AS. Calcitonin secretion by human placental tissue. Acta Obstetricia et Gynecologica Scandinavica 198766 323-326. (https://doi.org/10.3109/00016348709103646)

138 Bucht E, Telenius-Berg M, Lundell G \& Sjöberg HE. Immunoextracted calcitonin in milk and plasma from totally thyroidectomized women. Evidence of monomeric calcitonin in plasma during pregnancy and lactation. Acta Endocrinologica 1986113 529-535. (https://doi.org/10.1530/acta.0.1130529)

139 Krebs NF, Reidinger CJ, Robertson AD \& Brenner M. Bone mineral density changes during lactation: maternal, dietary, and biochemical correlates. American Journal of Clinical Nutrition 199765 1738-1746. (https://doi.org/10.1093/ajcn/65.6.1738)

140 Callies F, Arlt W, Scholz HJ, Reincke M \& Allolio B. Management of hypoparathyroidism during pregnancy - report of twelve cases. European Journal of Endocrinology 1998139 284-289. (https://doi. org/10.1530/eje.0.1390284)

141 Salle BL, Berthezene F, Glorieux FH, Delvin EE, Berland M, David L, Varenne JP \& Putet G. Hypoparathyroidism during pregnancy: treatment with calcitriol. Journal of Clinical Endocrinology and Metabolism 198152 810-813. (https://doi.org/10.1210/jcem-52-4-810)

142 Sadeghi-Nejad A, Wolfsdorf J \& Senior B. Hypoparathyroidism and pregnancy. Treatment with calcitriol. Journal of the American Medical Association 1980243 254-255. (https://doi.org/10.1001/ jama.1980.03300290036018)

143 Caplan RH \& Beguin EA. Hypercalcemia in a calcitriol-treated hypoparathyroid women during lactation. Obstetrics and Gynecology 199076 485-489.

144 Mitchell DM \& Jüppner H. Regulation of calcium homeostasis and bone metabolism in the fetus and neonate. Current Opinion in Endocrinology, Diabetes and Obesity 201017 25-30. (https://doi org/10.1097/MED.0b013e328334f041)

145 Eastell R, Edmonds CJ, De Chayal RC \& McFadyen IR. Prolonged hypoparathyroidism presenting eventually as second trimester abortion. British Medical Journal 1985291 955-956.

146 Hsu SC \& Levine MA. Perinatal calcium metabolism: physiology and pathophysiology. Seminars in Neonatology 20049 23-26. (https://doi. org/10.1016/j.siny.2003.10.002)
147 Shah KH, Bhat S, Shetty S \& Umakanth S. Hypoparathyroidism in pregnancy. BMJ Case Reports 2018. (https://doi.org/10.1136/bcr-2015210228)

148 Hatswell BL, Allan CA, Teng J, Wong P, Ebeling PT, Wallace EM, Fuller PJ \& Milat F. Management of hypoparathyroidism in pregnancy and lactation - a report of 10 cases. Bone Reports 20153 15-19. (https://doi.org/10.1016/j.bonr.2015.05.005)

149 Sweeney L, Malabanan A \& Rosen H. Decreased calcitriol requirement during pregnancy and lactation with a window of increased requirement immediately post partum. Endocrine Practice 201016 459-462. (https://doi.org/10.4158/EP09337.CR)

150 Bulloch MN \& Carroll DG. When one drug affects 2 patients: a review of medication for the management of nonlabor-related pain sedation, infection, and hypertension in the hospitalized pregnant patient. Journal of Pharmacy Practice 201225 352-567. (https://doi. org/10.1177/0897190012442070)

151 Ilany J, Vered I \& Cohen O. The effect of continuous subcutaneous recombinant PTH (1-34) infusion during pregnancy on calcium homeostasis-a case report. Gynecological Endocrinology 201329 807-810. (https://doi.org/10.3109/09513590.2013.813473)

152 Holick MF, Binkley NC, Bischoff-Ferrari HA, Gordon CM, Hanley DA, Heaney RP, Murad HM \& Weaver CM. Evaluation, treatment, and prevention of vitamin D deficiency: an Endocrine Society Clinical Practice Guideline. Journal of Clinical Endocrinology and Metabolism 201196 1911-1930. (https://doi.org/10.1210/jc.2011-0385)

153 Winer KK \& Yanovski JA. Synthetic human parathyroid hormone 1-34 vs calcitriol and calcium in the treatment of hypoparathyroidism. Journal of the American Medical Association 1996 276 631-636. (https://doi.org/10.1001/jama.1996.03540080053029)

154 Winer KK, Ko CW, Reynolds JC, Dowdy K, Keil M, Peterson D, Gerber LH, McGarvey C \& Cutler GB. Long-term treatment of hypoparathyroidism: a randomized controlled study comparing parathyroid hormone-(1-34) versus calcitriol and calcium. Journal of Clinical Endocrinology and Metabolism 200388 4214-4220. (https:// doi.org/10.1210/jc.2002-021736)

155 Winer KK, Sinaii N, Reynolds J, Peterson D, Dowdy K \& Cutler GB. Long-term treatment of 12 children with chronic hypoparathyroidism: a randomized trial comparing synthetic human parathyroid hormone 1-34 versus calcitriol and calcium. Journal of Clinical Endocrinology and Metabolism 201095 2680-2688. (https:// doi.org/10.1210/jc.2009-2464)

156 Winer KK, Zhang B, Shrader JA, Shrader JA, Peterson D, Smith M, Albert PS \& Cutler GB. Synthetic human parathyroid hormone 1-34 replacement therapy: a randomized crossover trial comparing pump versus injections in the treatment of chronic hypoparathyroidism. Journal of Clinical Endocrinology and Metabolism 201297 391-399. (https://doi.org/10.1210/jc.2011-1908)

157 Palermo A, Santonati A, Tabacco G, Bosco D, Spada A, Pedon C, Raggiunti B, Doris T, Maggi D, Grimaldi F et al. PTH (1-34) for surgical hypoparathyroidism: a 2 year prospective, open-label investigation of efficacy and quality of life. Journal of Clinical Endocrinology and Metabolism 2017103 271-280. (https://doi. org/10.1210/jc.2017-01555)

158 Liu XX, Zhu XY \& Mei GH. Parathyroid hormone replacement therapy in hypoparathyroidism: a meta-analysis. Hormone and Metabolic Research 201648 377-383. (https://doi. org/10.1055/s-0042-106970)

159 Sikjaer T, Rejnmark L, Rolighed L, Heickendorff L \& Mosekilde L. The effect of adding PTH (1-84) to conventional treatment of hypoparathyroidism: a randomized, placebo-controlled study. Journal of Bone and Mineral Research 201126 2358-2370. (https://doi. org/10.1002/jbmr.470)

160 Mannstadt M, Clarke BL, Vokes T, Brandi ML, Ranganath L, Fraser W, Lakatos P, Bajnok L, Garceau R, Mosekilde L et al. Efficacy and safety of recombinant human parathyroid hormone (1-84) in hypoparathyroidism (REPLACE): a double-blind, placebo-controlled, 
randomised, phase 3 study. Lancet Diabetes and Endocrinology 20131 275-283. (https://doi.org/10.1016/S2213-8587(13)70106-2)

161 Rubin MR, Cusano NE, Fan WW, Delgado Y, Zhang C, Costa AG, Cremer S, Dworakowski E \& Bilezikian JP. Therapy of hypoparathyroidism with PTH (1-84): a prospective six year investigation of efficacy and safety. Journal of Clinical Endocrinology and Metabolism 2016101 2742-2750. (https://doi.org/10.1210/ jc.2015-4135)

162 Misof BM, Roschger P, Dempster DW, Zhou H, Bilezikian JP, Klaushofer K, Rubin MR PTH(1-84) administration in hypoparathyroidism transiently reduces bone matrix mineralization. Journal of Bone and Mineral Research 201631 180-189. (https://doi. org/10.1002/jbmr.2588)

163 Cusano NE, Rubin MR, McMahon DJ, Irani D, Tulley A, Sliney J \& Bilezikian JP. The effect of PTH (1-84) on quality of life in hypoparathyroidism. Journal of Clinical Endocrinology and Metabolism 201398 2356-2361. (https://doi.org/10.1210/jc.2013-1239)

164 Sikjaer T, Rolighed L, Hess A, Fuglsang-Frederiksen A, Mosekilde L \& Rejnmark L. Effects of PTH(1-84) therapy on muscle function and quality of life in hypoparathyroidism: results from a randomized controlled trial. Osteoporosis International 201425 1717. (https://doi. org/10.1007/s00198-014-2677-6)
165 Astor MC, Løvås K, Debowska A, Eriksen EF, Evang JA, Fossum C, Fougner KJ, Holte SE, Lima K, Moe RB et al. Epidemiology and health-related quality of life in hypoparathyroidism in Norway. Journal of Clinical Endocrinology and Metabolism 2016101 3045-3053. (https://doi.org/10.1210/jc.2016-1477)

166 Vokes TJ, Mannstadt M, Levine MA, Clarke BL, Lakatos P, Chen K, Piccolo R, Krasner A, Shoback DM \& Bilezikian JP. Recombinant human parathyroid hormone effect on health-related quality of life in adults with chronic hypoparathyroidism. Journal of Clinical Endocrinology and Metabolism 2018103 722-731. (https://doi. org/10.1210/jc.2017-01471)

167 Andrews EB, Gilsenan AW, Midkiff K, Sherrill B, Wu Y, Mann BH $\&$ Masica D. The US postmarketing surveillance study of adult osteosarcoma and teriparatide: study design and findings from the first 7 years. Journal of Bone and Mineral Research 201227 2429-2437. (https://doi.org/10.1002/jbmr.1768)

168 Gafni RI, Guthrie LC, Kelly MH, Brillante BA, Christie CM, Reynolds JC, Yovetich NA, James R \& Collins MT. Transient increased calcium and calcitriol requirements after discontinuation of human synthetic parathyroid hormone 1-34 (hPTH 1-34) replacement therapy in hypoparathyroidism. Journal of Bone and Mineral Research 201530 2112-2118. (https://doi.org/10.1002/jbmr.2555)

Received 18 July 2018

Revised version received 29 October 2018

Accepted 10 December 2018 